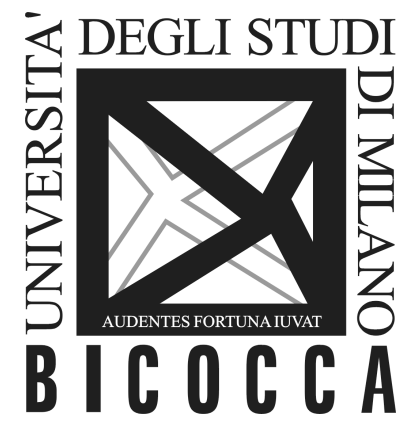

DEPARTMENT OF ECONOMICS

UNIVERSITY OF MILAN - BICOCCA

WORKING PAPER SERIES

Xenophobic Attacks, Migration Intentions and Networks: Evidence from the South of Africa

Guido Friebel, Juan Miguel Gallego and Mariapia Mendola

No. 213 - November 2011

Dipartimento di Economia Politica Università degli Studi di Milano - Bicocca

http://dipeco.economia.unimib.it 


\title{
Xenophobic Attacks, Migration Intentions and Networks: Evidence from the South of Africa ${ }^{1}$
}

\author{
Guido Friebel - Goethe University Frankfurt, IZA and CEPR \\ Juan Miguel Gallego - Universidad del Rosario and LdA \\ Mariapia Mendola - University of Milan Bicocca and LdA
}

\section{September 2011}

\begin{abstract}
We investigate how emigration flows from a developing region are affected by xenophobic violence at destination. Our empirical analysis is based on a unique survey among more than 1000 households collected in Mozambique in summe 2008, a few months after a series of xenophobic attacks in South Africa killed dozens and displaced thousands of immigrants from neighbouring countries. We estimate migration intentions of Mozambicans before and after the attacks, controlling for the characteristics of households and previous migration behaviour. Using a placebo period, we show that other things equal, the migration intention of household heads decreases from 37 to 33 percent. The sensitivity of migration intentions to violence is larger for household heads with many children younger than 15 years, decreasing the migration intention by 11 percentage points. Most importantly, the sensitivity of migration intentions is highest for those household heads with many young children whose families have no access to social networks. For these household heads, the intention falls by 15 percentage points. Social networks provide insurance against the consequences young children suffer in case the household head would be harmed by xenophobic violence and consequently could not provide for the family.
\end{abstract}

Keywords: violence, risk, migration, household behaviour, Mozambique JEL: O1, R2, J6, D1

\footnotetext{
${ }^{1}$ We thank Alice Mesnard, Melissa Myambo, Luca Stanca, Pedro Vicente and participants at the NORFACE-CREAM Conference on 'Migration, Economic Change and Social Challenge' at UCL in London, the CEPR-TOM Conference on 'International Migration: Transnational links, Effects and Policies' at Venice International University in Venice, the IZA Workshop on 'Legal and Illicit Immigration: Theory, Empirics and Policy' in Bonn and a seminar at the Goethe University in Frankfurt for comments and discussion. Financial support from Centro Studi Luca d'Agliano (LdA) for data collection is gratefully acknowledged. All errors are ours. Contact information: gfriebel@wiwi.uni-frankfurt.de, juan.gallego@urosario.edu.co, mariapia.mendola@unimib.it (corresponding author).
} 
Migration is one of the most important ways through which workers can improve their productivity and wages and increase their families' welfare. While the overall effects of migration on host and source countries alike seem to be beneficial, there have been through history fears of natives in host countries that migrants increase the unemployment among domestic workers and lower wages. History is full of examples in which domestic workers took violent actions against immigrants in order to deter migration. Examples include the anti-immigrant violence in $19^{\text {th }}$ century New York, which was documented by Asbury (1927), the recent violence against Hispanic migrants in the US, or the xenophobic violence in Eastern Germany after German re-unification.

It remains an open question how this form of violence affects migration and migration intentions. We here investigate how the migration flows from a developing region are affected by xenophobia and violent actions in a more developed host country. We investigate a hand-collected survey among more than 1000 households, administrated in Mozambique in summer 2008, a few months after a series of xenophobic attacks in South Africa killed dozens and displaced tens of thousands of migrants from neighbouring countries. Our identification strategy is based on the comparison of migration intentions of Mozambicans before and after the attacks occurred in May 2008, and on the use of a placebo period in which no violence occurred. We control for differing characteristics of the household samples (from a wide range of survey demographic measurements) and previous migration behaviour. We find that other things equal, the intention of the head of the household to migrate after the attacks is lower than before; it decreases from 37 percent to 33 percent. The sensitivity of migration intentions to violence is larger for household heads with many children younger than 15 years, decreasing the migration intention by 11 percentage points (p.p thereafter). Evidently, people are not only concerned about their own health, but also about the welfare of their offspring. Most importantly, the sensitivity of migration intentions is highest for households with many young children and little access to social networks. For such households, the intention falls by almost 15 p.p. Social networks thus provide insurance against the consequences small children suffer when the household head is harmed by xenophobic violence and consequently cannot provide.

The small but growing body of literature on violence and migration has focused on outmigration decisions in high-level violence environments (see Mesnard 2009 on out-migration flows from Colombia, for example). Yet, very little is known on how violence and xenophobic feelings in host countries affect migration intentions and behaviour in source countries. To the best of our knowledge this paper is the first that measures how violence or other types of xenophobic behaviour in host countries affect migration intentions, and to what extent social networks in the source country may provide insurance against the risks associated with migration. 
Our findings relate to intentions to migrate. A host of papers has looked at migration intentions (for instance, Burda et al., 1998; Drinkwater and Ingram, 2008; Epstein and Gang, 2006; Fouarge and Ester, 2007; Lam, 2000; Liebig and Sousa-Poza, 2004; Papapanagos and Sanfey, 2001; and Ubelmesser, 2006). Manski (1990) has questioned the general use of migration intentions data as a proxy for actual migration, but emigration intentions have been shown to be a good predictor of future actual emigration behaviour (see, for example, van Dalen and Henkens, 2008). It has also been argued that intentions are a monotonic function of the underlying driving variables that motivate migration (Burda et al.1998). Finally, using migration intentions data avoids the sample selection difficulties that arise from the use of the host country data (see Liebig and Sousa-Poza, 2004; van Dale and Henkens, 2008).

Our results shows that violence in the host country reduces the intention to migrate. Violence has the smallest effect on people who live in small households and have few children, and the largest on people with many household members whose family is badly connected to social networks. Migration intentions of household heads with large families who have a good social network are much less sensitive to violence than the ones with bad networks. This confirms that social networks are an important insurance mechanism in developing economies. However, the joint facts that (i) better access to social networks reduces the sensitivity of migration intentions to violence although (ii) access to networks in Mozambique cannot provide protection against violence in South Africa, lend itself to the interpretation that migrant workers seem to care more about the future of their offspring than about their own health.

The next section provides the necessary background on the two economies, Mozambique and South Africa, on the xenophobic violence in 2008, and the role of family and networks in Mozambique. Section 2 presents an illustrative model, and Section 3 the data. Section 4 discusses our empirical strategy that builds on the difference between the before and after violence intention to migrate, and the comparison with a placebo period that cannot be affected by the violence. Section 5 presents the main results, and Section 6 discusses a number of potential concerns about statistic identification. We then conclude.

\section{Migration from Mozambique, violence, and the role of family and networks}

Mozambique is one of the poorest countries in the world with a GDP per capita of $\$ 446$ at current US dollars in 2008. Out of 22.7 millions population, 70 percent of Mozambicans live below the poverty line- and 35 percent below the extreme poverty line (PRSP, 2007). Mozambique has had slow economic growth until the beginning of the 1990s, poor levels of education, especially of 
women, low productivity and a lack of employment opportunities. Basic infrastructure is lacking in many rural areas, whence the isolation of communities and poor integration of rural-urban markets (AfDB/OECD, 2003 and 2008). Faced with such poverty, migration is one of the few ways to improve the situation of a family. Because of its geographic proximity and much more advanced development, South Africa (SA) is the main destination of Mozambican migrant workers. SA is the African superpower and ranks as an upper-middle income economy with a GDP per capita of \$5.666 in current US dollars in 2008. The economic gap between Mozambique and SA in terms of development and growth is striking. Hence, South Africa seems to offer large economic advantages to potential migrants in Mozambique.

\section{TABLE 1 ABOUT HERE}

Panel A of Table 1 shows recent statistics about the stock of international migrants from Mozambique to OECD countries collected by Docquier et al. (2009). This dataset is collected from a population census in host countries where information about (legal) migration based on country of birth is available. The figures are quite similar to our representative household survey from two southern Mozambican Provinces shown in Panel B: the bulk of migrant workers from Mozambique go to South Africa.

Our empirical strategy is based on the comparison of migration intentions before and after xenophobic attacks, that is, the third quarter in 2007, compared to the third quarter in 2008, and the placebo period, the first quarter in 2008. The next table indicates that macroeconomic changes are not a driver of changes in intentions that we will observe.

\section{TABLE 2 ABOUT HERE}

Table 2 presents figures on inflation and GDP variation. There is no particular change in the third quarter (our period of reference) in 2007 and 2008 in both countries. The inflation rate in 2007 and 2008 in both countries follows the same trends in all terms of the year. At the end of 2007 cumulative price variation was 8.2\% in Mozambique and 7.1\% in South Africa. The numbers are slightly higher in 2008 (10.3\% and 11.5\% respectively). GDP has the same trend, without large changes between quarters in the two years, with the exception of the third quarter of 2008 where GDP in Mozambique fell by $0.14 \%$. If anything, this fall in the GDP should have triggered stronger migration intentions, had the xenophobic attacks not occurred. 
In May 2008, xenophobic violence exploded in South Africa. Violence was sudden: death and displacement rates reached a peak within weeks, as plotted in Figure 1.

\section{FIGURE 1 ABOUT HERE}

Since the early 1990s there had been isolated attacks on foreigners, but the scale and intensity of violence with which the events occurred were unpredictable for both national government and international organizations (Crush, 2008). The xenophobic riots in May 2008 constitute the first sustained nationwide eruption of social unrest since the end of Apartheid. Between May 11 and June 14, 62 people, the majority of them foreign nationals, were killed by mobs in Johannesburg, Cape Town, Durban and elsewhere. Xenophobic riots targeted foreigners living in townships and informal settlements in the main urban settlements of Gauteng and Western Cape provinces. The intensity of violence varied between provinces, in the Gauteng region the immigrants were exposed to intensive violence and victims often fled to escape imminent danger of being hurt or murdered. In the Western Cape province many fled in anticipation of the violence to come. The last reported attacks happened around one month later the $14^{\text {th }}$ of June, when a Mozambican man was burned alive in Atteridgeville township of Pretoria. At a stock of some ten thousand migrants in the affected region and 62 murders, there was a substantial risk, which explains the high displacement figures. Around 38,000 refugees were official reported by the United Nations but estimates of the number of displaced range between 80,000 and 200,000. (Igglesden et.al. 2009).

Poor households in developing countries face substantial risk from multiple sources but have typically limited access to formal insurance and credit markets. They therefore have to resort to informal arrangements with other households. The theoretical literature suggests that small groups or networks (e.g. Genicot and Ray, 2003; Ambrus, Mobius and Szeidl, 2010), with members who care for or trust each other and can punish reneging members, can achieve high levels of insurance (e.g. Altonji, Ayashi, and Kotliko, 1992; Foster and Rosenzweig, 2001; La Ferrara, 2003). The empirical evidence from a set of developing countries is consistent with these predictions (Ligon 1998; Fafchamps and Lund 2003; Dubois, Jullien, and Magnac 2008; Ambrus, Mobius, and Szeidl 2009). A relatively common presumption is that the extended family is the most important resourcesharing institution.

Yet, Coate and Ravallion (1993) argue that this is a rather "romanticized view" of kinshipbased sharing systems, and it has been shown that committing to enforcement is more difficult in homogenous kinship groups, where family obligations (the 'family tax') are likely to play a role 
(Anderson and Francois 2006). Recent empirical evidence considering endogenous formation of risk sharing groups in an economic experiment concludes that "genetically related individuals tend to distrust one another and so do not group when enforcement depends on intrinsic motivations alone” (Barr et al., 2008; Barr and Genicot, 2008).

Mozambique is peculiar in this respect. People in Mozambique predominantly organise their social life around their kin, and a person is perceived as 'incomplete' if she is not linked to an ascent group (including dead ancestors, through spiritism or witchcraft) or if she does not produce any descendants. However, polygamous marriages are common and much of family life is of temporary nature in Mozambique. Social relations typically extend into non-family forms, like relations with neighbours and xarás (quasi-kin), in addition to church relations, community group participation and friendships of varying degrees of formality. So alliances in southern Mozambique go beyond matrimonial linkages and beyond the kinship circle. This set of alliances defines a person, and the construction of this network is a subject's major investment for socio-economic life in Mozambique. ${ }^{2}$

We thus measure social networks beyond family links and focus on the relation of the family with social organizations and members of the community. In order to take into account the heterogeneity of social interaction, we distinguish between participation in (institutionalised) groups that provide economic benefits and (informal) mutual social arrangements with key members in the community (Miguel at al. 2006; Gallego and Mendola, 2010).

\section{An illustrative Model}

A simple model illustrates and sharpens our hypotheses. The model is not meant to explain migration decisions in general terms. Rather, it is supposed to explain while the migration decisions of some groups would react to violence in South Africa more intensively than others. In our model, households are heterogeneous with respect to two characteristics; first, the number of small children, and second, access to social networks. With respect to wages in Mozambique and South Africa we assume households to be homogeneous. This is correct with respect to wages in South Africa, but is a simplification with respect to Mozambique. We will, however, take this into account in the empirical part of the paper by controlling for wealth (as reliable income data are not available).

\footnotetext{
2 See Arfrend (2001) and Luiz Henrique Passador “Tradition, person, gender, and STD/HIV/AIDS in southern Mozambique”, ttp://www.scielo.br/pdf/csp/v25n3/24.pdf)
} 
Consider a household which maximizes its utility over two periods. The household takes decisions in line with the unitary model. It can send one household member to South Africa to work and this decision is taken with a view to maximize household utility, i.e., we abstract from any potentially diverging interests within the household. In the first period the household has the choice to migrate or to stay in Mozambique. In the beginning of the second period, the household member in question works in Mozambique. We choose this setting to simplify; permanent migration could be incorporated into the model, but would not add much. Moreover, most of the migrants from Mozambique are temporary.

We first look at the migration decision when there is no risk of violence. Assume that the household maximizes the sum of utilities over the migration decision $m$, where $m=1$ stands for migration, and $m=0$ for staying in Mozambique. To make things simple assume that time discount is nil, then the uitility of a family is $U=U_{1}(w(m), c(m), N)+U_{2}(w, N)$. The household's first-period utility depends on the wage it is paid, the costs of migrations, and the number of young children $N$. If the household member migrates to South Africa, the household receives $w_{S A}>w_{M O}$, i.e. the wage in South Africa is higher than the wage in Mozambique. The household member then has to pay migration costs $c$. If he does not migrate, he receives $w_{M O}$ and incurs no migration cost. In the second period, the household always receives $w_{M O}$. The household consumes any income it has in the period in which it accrues. Put differently, there is no access to credit markets.

In this simplistic model, it is immediately clear that the household member will migrate if and only if the net benefit of migration $w_{S A}-w_{M O}-c>0$. As we are not interested in knowing about migration decisions in general, we do not impose structure on the utility function with respect to the number of children $N$. Rather we want to know which groups should be most and least affected by the violence in South Africa. We hence allow for the risk of violence in South Africa to affect the second-period wage in Mozambique. Without violence, the wage at home would not be affected by migration, but when the household member becomes a victim of violence in South Africa, his productivity will be severely affected. The household member takes a risk to die or be severely hurt. Consequently, the expected wage in Mozambique in the second period can be written as $E\left(w_{M O 2}(m=1)\right)<w_{M O 2}(m=0)$.

To derive predictions about the type of household members most affected by violence in South Africa, it suffices to assume that $\delta^{2} U / \delta N \delta w>0$ (at least for a sufficiently large wage shock). This means that a decrease in the expected wage $w$ will affect the utility of a family with many children more strongly than one with less young children. The idea behind the assumption is that when there is a negative wage shock, the household may not have enough income to feed its children, leading to famine, illness or death of children, which strongly affects the utility of the 
household. Our assumption is founded on a very simple fact. To keep a child (or any human being) healthy a minimum amount of calorie intake per day is required. A family with less children, other things equal, can adapt its consumption pattern to a change in income in a way that all children stay healthy, but a household with more children will ultimately reach the critical calorie level.

The effect of access to a network is also quite simple: households that are in a network can get some transfer compensating in part for the wage loss. Consequently, the decrease in secondperiod consumption will be weaker. Notice that we assume that network membership to be exogenous and that we are not concerned about investments in the network or how the transfer is paid back. We simply consider that network access can overcome (partially) the credit constraints developing economies suffer from. We do not claim any deep theoretical insights, neither do we try to explain migration decisions in general. Rather, we seek to explain the observed heterogeneity the in sensitivity of migration intentions to violence.

\section{Data}

The data used in our empirical analysis is based on a unique survey conducted by Gallego and Mendola in 42 communities (both urban and rural) in 2 Provinces (Maputo and Gaza) in the South of Mozambique. The survey was conducted in August 2008 and contains information on household migration intentions after South African xenophobic attacks along with detailed demographic characteristics of household members, migration status, educational levels, household asset endowments, and formal and informal social networks from a sample of 1002 households.

The sample is representative at the regional level and demographic, ethnic and community characteristics are very similar to distributions of the general population living in the South of Mozambique (Maputo and Gaza Provinces). The sampling design was subject to a standard twostage procedure, which first select communities (enumeration areas), and then households. In particular, our sampled communities were chosen randomly, weighting by the number of individuals using the most recent national Census implemented in 2007 by the Mozambican National Statistical Institute (INE). In each community the population has been canvassed prior to the beginning of the fieldwork to identify two groups, i.e. households with at least one current international migrant and households with no migrants. The target number of households has been drawn randomly from each of the two subgroups, in the same proportion as the actual migration rate.

We designed the questionnaire to, among other things, shed light on the effect of xenophobic attacks in South Africa on migration intentions of people in Mozambique. The survey 
respondent is typically the best informed adult in the household. Although the survey instruments follow the methodology of the Living Standard Measurement Studies of the World Bank, they were tailored to allow accurate measurement of migration experience of each adult member in the household and migration intentions for different periods of interest.

With respect to migration intentions, retrospective information was asked on current migration intention (in August 2008) and past migration intention (1 year earlier) of household members. The brief period of time that elapsed between the time of the survey and the xenophobic attacks should foster a good perception of current and past intentions. Moreover, we can control for a "good old times" bias and for any other aggregate shock that might affect migration intentions even in the absence of xenophobic attacks by using the same information relative to a 'placebo' period (when no major occurrence had arisen). ${ }^{3}$

Thus, the survey questions are as follow: (i) 'Do you or any member of your household have any intention to migrate to South Africa in the next 6 months?', (ii) Are you aware of the xenophobic attacks occurred in South Africa in the last few months?' (iii) Did you or any member of your household have any intention to migrate to South Africa in the last year?' (iv) Did you or any member of your household have any intention to migrate to South Africa in the last 6 months? (placebo period)'. Answers to migration intentions were chosen from the pre-set list of four alternatives: ‘no intention' ‘weak intention', ‘strong intention', ‘surely’.

The survey instruments include socioeconomic and demographic characteristics followed by the information on migration experience and group participation. Data on migration of household members were also gathered, including information on duration and destination of migration, and whether migration involved moving costs and remittances. In addition, a community questionnaire was implemented to the community leader to collect information on the institutional and market organization, community infrastructure and social cohesion.

Overall, 95\% of our sample households report to be aware of the xenophobic attacks that occurred in South Africa in May 2008. Positive migration intentions are plotted in Figure 2. 33\% of our sampled household respondent had no intention to migrate in 2008 compared to 37\% 6 months and 1 year before the year of the survey. The difference between one year before and the placebo moment 6 months before is negligible while the difference to 2008 is statistically significant. Descriptive statistics of main variables of interest can be found in Tables 3 to 5 .

\section{FIGURE 2 ABOUT HERE}

\footnotetext{
${ }^{3}$ See Vicente (2010) for a paper using a similar methodology.
} 


\section{TABLES 3 TO 5 ABOUT HERE}

Table 3 presents the distribution of migration intentions across the four categories over the periods of reference and we observe a decrease of any positive migration intention from 2007 to 2008. The Tables show some asymmetries in migration intention between subgroups of population, such as households with different size, or households with different levels of 'social networks', which we will control for in regressions.

\section{TABLE 6 ABOUT HERE}

Descriptive statistics for our control variables are presented in Table 6, which reports demographics, educational attainments, wealth position, international migration experience and community characteristics. Data shows that $38 \%$ of households have a female head and the average household size is 5.4 members. If we look at the migration experience, 38\% reported at least one current international migrant in the household and 27\% has past migration experience.

Household wealth is measured through a synthetic asset index weighting the ownership of various durable goods and the dwelling conditions. The methodology to build the index uses principal components analysis to assign weights to the indicator (see Filmer and Prichett, 2001) and a large number implies better economic position of the household.

\section{Empirical strategy}

The estimation approach is based on comparing migration intentions about the periods before May 2008 and after, while controlling for differing characteristics of the household samples (from a wide range of survey demographic measurements) and differing time perception. We estimate migration intentions as follows:

$$
P_{i t}=\beta_{0}+\beta_{1} M_{i t}+\beta_{2} X_{i}+\gamma T_{1}+\varepsilon_{i t}
$$

where Pit is an indicator for migration intention in household $i$ in year $t$ (with $t=$ August2007, August2008); $T_{1}$ is a dummy that takes the value one if the observation comes from the period after attacks (August2008), and zero otherwise; Mit measures the migration experience in the household at present and in the past.; and $X i$ is a vector of individual and family characteristics, including age education, household demographics, and community of residence. Standard errors will be estimated 
allowing for clustering at the household level as the error is serially correlated because of repeated observations for the same household.

The main identification issue of this equation estimation arises from the fact that the estimated coefficient $\gamma$ captures not only the effects of the attacks, but also of any other time-varying factors contemporaneous with the attacks that might have affected migrants' intention behaviour. To disentangle the effects of xenophobic attacks from any other time trend effects of the economy, besides controlling for a wide range of household and community characteristics as well as community fixed effects, we include the "placebo period effect” in the equation as follows:

$$
P_{i t}=\beta_{0}+\beta_{1} M_{i t}+\beta_{2} X_{i}+\gamma T_{1}+\varphi T_{2}+\varepsilon_{i t}
$$

where $T_{2}$ takes value one if the observation comes from the placebo period (January 2008). We expect the coefficient of this variable to be non-significant, as no major changes occurred with respect to August 2007. Yet, in order to control for migration seasonality issues, we further include as an extra control whether households experienced seasonal migration of household members.

Furthermore, we investigate whether the household sensitivity to xenophobia at destination varies systematically according to key exogenous socio-demographic characteristics. Given the issues - pointed out by $\mathrm{Ai}$ and Norton (2003) - in the estimation of the marginal effects of interaction variables in logistic regressions, we present marginal impact effects of heterogeneous 'before-and-after estimates' across sub-samples of households. In particular, we estimate heterogeneous effects with respect to the household structure and its engagement in communitybased social networks. With respect to the former, we divide the sample into two sub-samples according to the household size and composition. With respect to social networks participation, the subsample consists of households with and without membership in community-based socioeconomic groups. Finally, we estimate heterogeneous effects across the intersection of the above mentioned sub-samples of households, as to test to what extent households' demographic attributes combined with social networks participation increase (or decrease) the cost of migration due to high risk at destination.

\section{Results}

Table 7 summarises probit regression results, where the dependent variable is a binary variable equal to 1 if the household respondent reports a positive intention to emigrate of any household member (i.e. whether the answer to migration intentions reported above is any of the following 
alternatives: ‘weak intention', ‘strong intention', ‘surely’). The dependent variable is equal to 0 if the answer is 'no intention'. 4

\section{TABLE 7 ABOUT HERE}

In order to directly interpret the results, we report marginal (or discrete) effects, which are the changes in the predicted probability associated with changes in the explanatory variables. In Table 7, we begin with a restricted specification and then include household and community controls, community fixed effects and other specific controls related to the 'placebo effect'. Controls include: gender, age and occupation of household head, household size, number of females and children (0-4) in the household, household ethnicity and religion, average years of schooling in the household, and a household wealth indicator. The last two variables are included also in squared terms as to allow for a potential non-linear relationship between migration intentions and the household skill and wealth position. We further include a dummy variable for urban areas and community level characteristics, such as the quality of roads, school and health facilities, formal bank and market availability. We finally rule out any unobservable community level characteristics potentially associated with variation in migration intentions and we fully focus on the withincommunity variation by running specifications with community fixed effects (where the community is our primary sampling unit). Including community fixed effects allow us to control for any difference across communities which might affect the level of migration, such as differences in attitudes towards migration, migration history and networks, infrastructure and labor market characteristics.

In all specifications, with both controls and community fixed effects, Mozambicans' intentions of migrating is estimated to decrease after the xenophobic shock occurred in South Africa. Adding controls for the household migration experience does not reduce the significance of the post-attack drop nor its dimension. In particular, in the less parsimonious specification, other things being equal, the average propensity to migrate after the attacks is lower than before by 4.6 percentage points ("p.p." hereafter). Importantly, the placebo period has no effect on migration intentions - while controlling also for seasonal migration experience. The community fixed effects estimates in the two last columns of Table 7 show that if there are differences in the labor market conditions as well as migration experience across communities they are ruled out by focusing on variation within communities.

\footnotetext{
${ }^{4}$ Since the ordered probit results are harder to summarize, we use the dichotomous measure by aggregating the different degrees of positive migration intentions and estimate probit specification. Yet, we also run ordered probit regressions using the four categories and results are available upon request.
} 
It is worth noting that there is a significant non-linear relation between the wealth index and the intention to migrate. In particular, at low levels of wealth a marginal increase in wealth raises propensity to migrate. For better-off households, instead, a marginal increase in wealth decreases migration intention. This reflects the fact that migration is both a costly and risky process, but also remunerative in terms of remittances, such that poorer households facing less credit constraints may need to migrate more than richer households ${ }^{5}$.

Overall, our results on the time dummies suggest that a drop in the propensity to migrate between August 2008 and August 2007 is attributable to South African violence episodes that occurred in May 2008. Above results represent an average from very heterogeneous households.

To learn more about how different types of households behave, and what role social networks play, we run the same probit regressions in a set of population sub-samples according to some predetermined household characteristics. These models assess whether and how much these household characteristics reduce (or increase) the cost of xenophobic violence at destination. Tables 8-10 present probit marginal effects for a set of sub-groups defined by observable household attributes correlated with both migration intentions and the risky nature of migration behaviour, that is (i) the number of household members (both adults and children); (ii) the degree of household engagement in community based social networks (i.e. household membership in a community group and household engagement in informal exchanges of goods or services with other households in the community); (iii) the intersection of both household structure and social networks.

\section{TABLE 8 ABOUT HERE}

Results show that larger households are more sensitive to the xenophobic shock - in other words, the average decrease in migration intentions after the shock is mostly due to large households' responses. Furthermore, other things equal, households with more children (i.e. more than 4 children of 0-15 years old) are less likely to migrate after the shock by 11 p.p. (Panel BTable 8).

In addition, we run regressions differentiating households according to the number of female members as to control for the fact that while household heads are keen to insure welfare of their family, women's labor supply at home might perform an insurance function at household level. Yet, this is not the case as results go in same direction as above with xenophobic attacks affecting more the intention to migrate of households with many females (Panel C- Table 8). This reflects the

\footnotetext{
${ }^{5}$ The estimated parameters of wealth index and the square term, in any specification of table 7 , show that the maximum on the relation between migration intention and wealth belongs to the relevant interval of the wealth index (see table 6 and table 7 for a comparison).
} 
strong patriarchal structure of the Mozambican society, particularly in the South of the country, and the extremely low participation of women in the labor market as well as in several aspects of the local socio-economic life. We have also run robustness checks including adult children, who through their work may provide some insurance in case the household head is affected by violence, but nothing changes (see Tab A1 in Appendix).

\section{TABLE 9 ABOUT HERE}

Table 9 reports the same regression specification as above across subsamples of households, according to their engagement in community-based social networks. Results show that households with no group membership or no informal social networks are less likely to migrate after the shock by more than 6 p.p. This seems to suggest that people who do have access to a social buffer have a much lower sensitivity of migration intentions than people who have no access to social networks.

\section{TABLE 10 ABOUT HERE}

In Table 10 we further explore the interplay between family structure and social insurance in affecting risky migration behaviour. Results show that social networks do not have the same 'mitigating effect' effect on migration intentions when people have few children or households are small. Large families with no social networks, however, significantly decrease their likelihood to migrate by 15 p.p.. This seems to suggest that, according to the theory, having family (and children) has a deterrent effect in risky migration behaviour, but if the family is 'well connected' this mitigating effect disappears.

So far we have run separate regressions for household sub-samples as to allow the effect of xenophobic attacks to interact with household level characteristics. In order to test whether the difference between our heterogeneous before-and-after estimates are statistically significant, we run specifications with controls for the interactions between the xenophobic shock - as well as the placebo variable - and household level characteristics that influence both the degree of risk and insurance. Results reported in Tables A2-A5 in Appendix test the main effects of the xenophobic attacks and the household level characteristics, while also testing if the xenophobic shock has an effect on the slopes of these characteristics. Because in probit regression the interpretation of 
interaction effects is complicated (Ai and Norton, 2003), we only report the coefficients (not odds ratios) and concentrate on significance and direction. ${ }^{6}$

In Table A2 we test interaction effects of the xenophobic shock with household demographic characteristics, i.e. household size, number of children and number of females, using the latter as continuous (panel A) and discrete variables (panel B). The same variables are interacted with the placebo period. Table A3 adds to models in Table A2 community fixed effects as controls. In Table A4 we test interaction effects with household group participation. Overall, compared to models in Tables 8-9, we find consistent results for household-level variables and interaction terms. While the main effect of the time dummy for the xenophobic shock is not significant, the time dummy interacts significantly with the three household demographic characteristics. This is to say that household demographic characteristics have a significant impact on the difference of migration intentions before and after the xenophobic shock. In particular, large households, and households with many children and females are significantly more sensitive to the xenophobic shock with respect to smaller households or families with few dependents. Households with group membership, on the other hand, are not significantly more (or less) sensitive to the xenophobic shock, whilst the latter still has a significant negative main effect on migration intentions. ${ }^{7}$

Finally, Table A5 reports regression results including interaction effects of time dummies with the three groups of demographics combined with household group participation. In particular, building from models in Table 10, we estimate an equation that allows for differences in migration intentions among four groups: small households with group membership, large households with group membership, small households with no group membership, and large households with no group membership. The estimation of a specification with three dummy variables (and one base category) allows us to assess the proportionate difference in migration intentions with respect to the base group. Results show that households with many children and no group membership are significantly more sensitive to the xenophobic shock with respect to small households with no group membership (base group)- but the same does not hold for large households with group membership, whose coefficient is not significant. This seems to suggest that the latter group of households is more protected via group membership.

Overall, the results are consistent with our predictions: violence has the smallest effects on migration intentions in households without kids and the largest on people with kids whose family is

\footnotetext{
${ }^{6}$ We also run additional models to estimate interaction effects. We run both Linear Probability Models (LPM) and probit model marginal effects using the command inteff in Stata developed by Norton, Wang and Ai (2004). The latter command allows to compute the correct marginal effect and significance of the interaction variable in a probit model. Results are consistent with those reported in Tables A2-A5 in Appendix (results available upon request).

${ }^{7}$ We also test interaction effects of informal social ties as a measure of social networks, finding similar results as using household group participation (results available upon request).
} 
badly connected. People with kids who have a good network will be less sensitive than the ones with bad networks.

\section{Discussion}

A first important question is whether networks may affect labor outcomes in South Africa. Consider that people who are better connected in Mozambique would receive higher wages. We would then measure a simple wage effect, rather than the insurance effects of social networks against the risk of death or injury of the household head. The wage effect would, however, not explain why it is particular families with young children whose migration intentions are affected by social networks. Moreover, we know that migrants from Mozambique sell their work on the South African spot market to South Africans. (Table 11 lists the distribution of occupations among our sampled individuals employed in SA.)

\section{TABLE 11 ABOUT HERE}

Being connected in Mozambique thus should not substantially affect the South African labor market outcome. Network membership may affect the wage in Mozambique, though. But if anything, this would make our results even stronger, because it would imply that connected people would be less, and not more likely to migrate.

A second, related, question is whether being a network member could reduce the risk of being harmed in South Africa. However, it seems little convincing to believe that network membership in Mozambique could help people against street violence in South Africa, where people who would be identified as non-natives could become victim at any time during the riots.

A third concern is that people with higher levels of trust in the society as a whole participate more in social networks and also are more willing to take the risk and migrate to South Africa. If this was the case we would be capturing a spurious relation between networks and migration intentions. Yet, this argument would entail that people's trust should be related to both Mozambican and South African society in the same way, which is unlikely given the large differences between the two countries. And, this argument would still fail to explain why it is in particular in large families where migration intentions decrease.

On a more general level, it could be argued that social networks are not exogenous to migration behaviour. There is indeed ample evidence that immigrants' social networks in the country of destination are important, because former migrants help newcomers to settle down, while 
far less evidence exists on the role of group participation and social arrangements at origin (see Munshi and Rosenzweig, 2009, for an exception). However, we have evidence that indicates that it this is not the case in Mozambique. Rather, family plays an important role on migration behaviour (see Table 12).

\section{TABLE 12 ABOUT HERE}

Household with migrants in our survey answered that the main source of help in the migration process was family members at origin or destination (46\% for current migrants and $51 \%$ for returned migrants), followed by their own experience (34\% for current migrants and $24 \%$ for returned migrants). In addition, family members give housing at destination to the new migrants (40\% of current migrants live with some family members). Second, as we have included community fixed effects in our estimates, we do control for the community migration network (i.e. the proportion of former migrants in a given community), which could lower the costs of migrating and finding a job at destination (cf Massey, 1988; Massey, Goldring and Durand 1994; Dolfin and Genicot, 2006; McKenzie and Hillel Rapoport 2007). Notice also that we do not look at the onset of the migration phenomenon in Mozambique, when social help through networks would be particularly important. Rather, migration between Mozambique and South Africa is a long-lasting and widespread phenomenon. While Mozambicans have historically been the main labour force for South African mines, most of today’s migration from Mozambique is not permanent (life cycle), but temporary or circular migration, for which the role of networks is believed to be less important (Massey, Goldring and Durand, 1994). ${ }^{8}$

The SA Census in $2001^{9}$ shows that Mozambicans are low-skill migrants and they do not cluster at one particular occupation as would likely be the case if a migration network is acting at destination. Migrants serve in different occupations (agricultural, mining, construction and retail trade, see panel A and panel B of Table 13).

\section{TABLE 13 ABOUT HERE}

Panel C of Table 13 also shows that Mozambican migrants spread over four provinces located in the north region of South Africa (North West, Gauteng, Mpumalanga and Limpopo). Panel C shows that $97 \%$ of Mozambican migrants do not cluster but spread over the four northern

\footnotetext{
${ }^{8}$ From our survey we know that $80 \%$ of the current migration is temporary migration. The average duration of the migration spell by returned migrants is nine months.

${ }^{9}$ The most recent South African census refers to the year 2007, but there is not information on the country of origin for migrants. The census of 1996 shows the same path that those presented here for the 2001 census.
} 
provinces in South Africa (North West, Gauteng, Mpumalanga and Limpop), which is consistent with the idea of cross-border migration phenomenon between Mozambique and South Africa. The path of location is similar to the flows of migrants from other African countries (with Zimbabwe as the main sending country after Mozambique), but different from the location of non-African migrants who cluster mainly on two provinces Western Cape (the region of Cape Town) and Gauteng (the region of Johannesburg).

We hence argue that group participation in Mozambique is exogenous to migration behaviour and labor market outcomes (wages) of immigrants in South Africa, as well as to the migrant's likelihood to be hit by xenophobic attitudes in regions of destination.

Finally, by comparing migration intentions from different communities in a single one-year period (before and after exogenous xenophobic shocks), we are much less concerned about the interaction between community networks and labor market outcomes in Mozambique as well. This is so as access to groups and social networks is not an open process, but there are frictions to participation such as transactions costs, imperfect commitment, asymmetric information, lack of enforceability or any other process that limits informal social arrangements (see Fafchamps, 2002, Ligon et al., 2002). Thus, we can rule out the possibility that households start joining networks at origin due to xenophobic attacks at destination over such a short period of time.

\section{Concluding Remarks}

By using a unique representative household survey collected in Southern Mozambique in summer 2008 we have shown that migration intentions to South Africa have been affected substantially after violent xenophobic attacks. Migration may have important development effects on both South Africa and other African origin countries. However, given the hardening of anti-immigration feelings and xenophobic behaviour, not only in South Africa, it is of interest to understand how these attitudes at destination affect out-migration behaviour in countries of origin.

Our identification strategy is based on the comparison of migration intentions of Mozambicans before and after the attacks occurred in May 2008, and on the use of a placebo period in which no violence occurred. Our results show that other things equal, the migration intention of household heads decreases by no less than 4 p.p. after the attacks. We also estimate heterogeneous before-and-after effects across sub-samples of households according to some predetermined sociodemographic characteristics. We find that the impact of violence on migration intentions is largest for household with many young children. Access to social networks mitigates the perceived danger, though. The sensitivity of migration intentions is highest for those household heads with many 
young children whose families have no access to social networks. For these household heads, the intention falls by 15 p.p. Social networks hence seem to play an important role as an insurance device against the risks associated with migration. Social networks in the country of origin cannot offer protection against violence in the destination country, but they can insure families against the income losses owing to injury or death of the household head. According to our study, violence in a destination country may constitute a massive obstacle for migrants, in particular, for those that leave large families behind with little access to social insurance arrangements. 


\section{REFERENCES}

AfDB/OECD (2003). African Economic Outlook 2002/2003. Country Studies: Mozambique. OECD and African Development Bank, Paris.

AfDB/OECD (2008). African Economic Outlook 2008. Country Studies: Mozambique. OECD and African Development Bank, Paris.

Ai, C. and Norton, E. (2003). "Interaction Terms in Logit and Probit Models.” Economic Letters, 80, 123-129.

Altonji, L., F. Hayashi, and Kotliko L. (1992). "Is the Extended Family Altruistically Linked? Direct Tests Using Micro Data.” American Economic Review, 1177-98.

Ambrus, A., Mobius, M. and Szeidl, A. (2010). "Consumption Risk-Sharing in Social Networks.” NBER Working Papers 15719, National Bureau of Economic Research.

Anderson, S. and Francois, P. (2008). "Formalizing Informal Institutions: Theory and Evidence from a Kenyan Slum.” In: Institutions and Economic Growth, Helpman, E. (ed.), Harvard University Press.

Arnfred, S. (2001). "Family Forms and Gender Policy in Revolutionary Mozambique (1975-1985)" Centre d'Étude d'Afrique Noire: Travaux et Documents, 68-69, 1-34.

Asbury, H. (1927). “The Gangs of New York: An Informal History of the Underworld.” Reprint by Dorset Press.

Barr, A., M. Dekker and Fafchamps, M. (2008). "Risk Sharing Relations and Enforcement Mechanisms.” Oxford University, Mimeo.

Barr, A. and Genicot, G. (2008). "Risk Sharing, Commitment and Information: An Experimental Analysis.” Journal of the European Economic Association, in Press.

Burda, M. C., Härdle, W., Müller, M. and Werwatz, A. (1998). "Semiparametric Analysis of German East-West Migration Intentions: Facts and Theory." Journal of Applied Econometrics, 13(5), 525-541.

Coate, S. and Ravallion, M. (1993). "Reciprocity without Commitment : Characterization and Performance of Informal Insurance Arrangements." Journal of Development Economics, 40(1), 124.

Crush, J. (2008). “The Perfect Storm: The Realities of Xenophobia in Contemporary South Africa. The Southern Africa Migration Project.” Migration Policy Series, 50.

Van Dalen, H. P. and Henkens, K. (2008). "Emigration Intentions: Mere Words or True Plans? Explaining International Migration Intentions and Behaviour.” Discussion Paper 2008-60, Tilburg University, Center for Economic Research.

Docquier, F., Lowell, B. and Marfouk, M. (2009). “A Gendered Assessment of Highly Skilled Emigration.” Population and Development Review, 35(2), 297-322. 
Drinkwater, S. and Ingram, P. (2008). "How Different are the British in Their Willingness to Move? Evidence from International Social Survey Data.” Regional Studies, 1-17.

Dubois P., Bruno J. and Magnac T. (2008). "Formal and Informal Risk Sharing in LDCs: Theory and Empirical Evidence.” Econometrica, 76(4), 679-725.

Epstein, G. S. and Gang, I. N. (2006). “The Influence of Others on Migration Plans.” Review of Development Economics, 10(4), 652-665.

Fafchamps, M. and Lund, S. (2003). "Risk Sharing Networks in Rural Philippines.” Journal of Development Economics, 71(2), 261-287.

Filmer, D. and Prichett, L. (2001). "Estimating Wealth Effects without Expenditure Data or Tears: An Application to Education Enrolments in States of India.” Demography, 38(1),115-132.

Foster, A. and Rosenzweig, M. (2001). "Imperfect Commitment, Altruism and the Family: Evidence from Transfer Behavior in Low-Income Rural Areas.” Review of Economics and Statistics, 83(3), 389-407.

Fouarge, D. and Ester, P. (2007). "Determinants of International and Regional Migration Intentions in Europe.” Office for Official Publications of the European Communities, Luxembourg.

Genicot, G. and Ray, D. (2003). "Group Formation in Risk-Sharing Arrangements." Review of Economic Studies, 70(1), 87-113.

Igglesden, V., Monso, T. and Polzer, T. (2009). "Humanitarian Assistance to Internally Displaced Persons in South Africa: Lessons Learned Following Attacks on Foreign Nationals.” Forced Migration Studies Programme, University of the Witwatersrand.

Katz, E. and Stark, O. (1986). "Labor Migration and Risk Aversion in Less Developed Countries.” Journal of Labor Economics, 4 (1), 134-149.

La Ferrara, E. (2002). "Inequality and Group Participation: Theory and Evidence from Rural Tanzania.” Journal of Public Economics, 85(2), 235-73.

Lam, K.-C. (2002). "Interaction Between Economic and Political Factors in the Migration Decision.” Journal of Comparative Economics, 30(3), 488-504.

Liebig, T. and Sousa-Poza, A. (2004). "Migration, Self-Selection and Income Inequality: An International Analysis.” Kyklos, 57, 125-146.

Ligon, E. (1998). "Risk Sharing and Information in Village Economics" Review of Economic Studies, 65(4), 847-64.

Manski, C. F. (1990). "The Use of Intentions Data to Predict Behaviour: A Best-Case Analysis.” Journal of American Statistical Association, 85(412), 934-940.

Massey, D. S. (1988). "International Migration and Economic Development in Comparative Perspective.” Population and Development Review, 14, 383-414. 
Massey, D. S., Goldring, L. P. and Durand, J. (1994). "Continuities in Transnational Migration: An Analysis of 19 Mexican Communities.” American Journal of Sociology, 99, 1492-1533.

Mendola, M. (2008). "Migration and Technological Change in Rural Households: Complements or Substitutes?” Journal of Development Economics, 85(1-2), 150-175.

Mesnard, A. (2009). “Migration, Violence and Welfare Programmes in Rural Colombia.” IFS Working Paper W09/19.

Miguel, E., Gertler P. and Levine, D. (2005). "Does Industrialization Build or Destroy Social Networks?” Economic Development and Cultural Change, 54(2), 287-318.

Norton, E., Wang, H. and Ai, C. (2004). "Computing Interaction Effects and Standard Errors in Logit and Probit Models”, Stata Journal, 4(2), 154-167.

Papapanagos, H. and Sanfey, P., (2001). "Intention to Emigrate in Transition Countries: The Case of Albania.” Journal of Population Economics, 14(3), 491-504.

PRSP (2007). “Republic of Mozambique: Poverty Reduction Strategy Paper.” IMF Country Report No. $07 / 37$.

Stark, O. and Levhari D. (1982). “On Migration and Risk in LDCs.” Economic Development and Cultural Change, 31(1), 191-196.

Uebelmesser, S. (2006). “To Go or Not to Go: Emigration from Germany.” German Economic Review, 7(2), 211-231.

Vicente, P. (2010). "Does Oil Corrupt? Evidence from a Natural Experiment in West Africa." Journal of Development Economics, 92(1), 28-38.

Wa Kabwe-Segatti, A. and Landau, L. (2008). "Migration in Post-Apartheid South Africa:Challenges and Questions to Policy-Makers”, AFD Notes \& Documents No. 38, Paris.

Yang, D. and Choi, H. (2007). "Are Remittances Insurance? Evidence from Rainfall Shocks in the Philippines.” World Bank Economic Review, 21(2), 219-248. 


\section{TABLES AND FIGURES}

Figure 1: Xenophobic attacks in SA: cumulative distribution of killed and displaced people over time (May-June 2008)
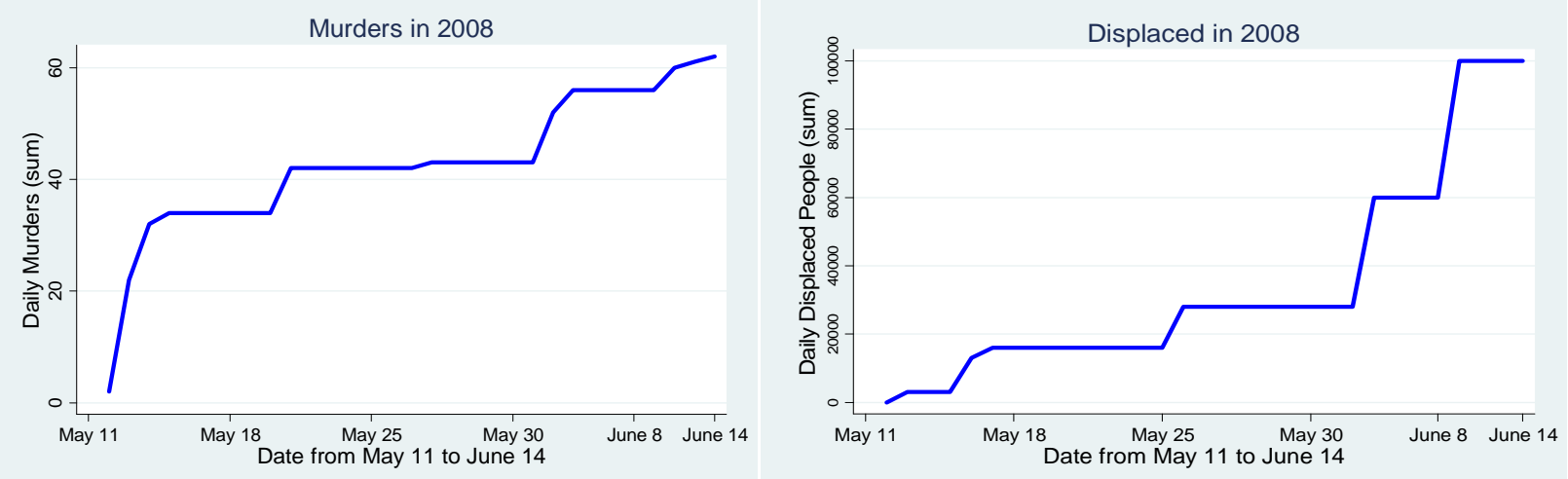

Source: Authors' calculation from several newspapers, magazines and news cables (e.g. CNN, BBC, ABC, Le Monde, El Pais, Times ZA, The Guardian)

Figure 2: Incidence of positive migration intention over time

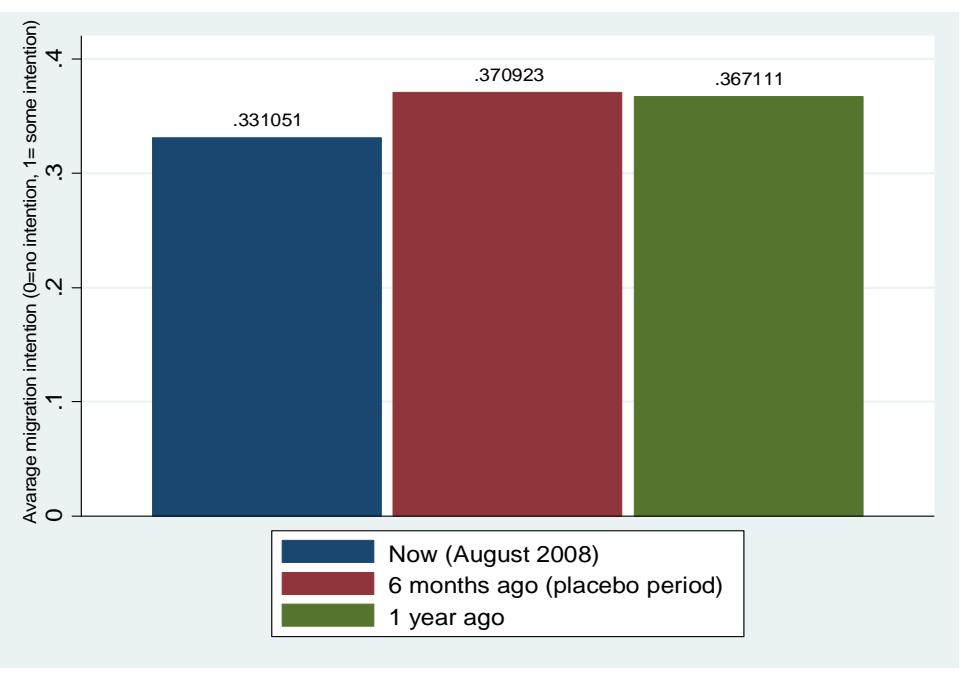


Table 1: International migration in Mozambique

\begin{tabular}{lcc}
\hline \multicolumn{3}{c}{ Panel A: Mozambican immigrants by OECD country of destination* } \\
\hline & $\mathbf{1 9 9 0}$ & $\mathbf{2 0 0 0}$ \\
\cline { 2 - 3 } South Africa & $95.50 \%$ & $93.80 \%$ \\
Other OECD country & $4.50 \%$ & $6.20 \%$ \\
\hline
\end{tabular}

*Source: Docquier et al (2009)

Panel B: Mozambican emigrants by country of destination (2008)**

\begin{tabular}{lcc} 
& Past Migrants & Current Migrants \\
\cline { 2 - 3 } South Africa & $90.30 \%$ & $97.90 \%$ \\
Other african countries & $8.30 \%$ & $1.50 \%$ \\
Other (Europe/USA) & $1.30 \%$ & $0.60 \%$ \\
\hline
\end{tabular}

**Source: Our survey in Southern Mozambique. 


\begin{tabular}{ccccc} 
Quarter & \multicolumn{2}{c}{$\begin{array}{c}\text { CPI variation 12 months } \\
\text { (average) }\end{array}$} & \multicolumn{2}{c}{$\begin{array}{c}\text { GDP variation (\%) } \\
\text { Quarter var. }\end{array}$} \\
\hline & \multicolumn{3}{c}{ Mozambique } & \multicolumn{2}{c}{$\mathbf{2 0 0 8}$} \\
\hline & $\mathbf{2 0 0 7}$ & $\mathbf{2 0 0 8}$ & $\mathbf{2 0 0 7}$ & 4.52 \\
2 & 11.04 & 9.62 & 1.33 & 1.2 \\
3 & 9.04 & 10.35 & 1.62 & -0.14 \\
4 & 8.55 & 10.68 & 1.77 & 3.4 \\
Annual & 8.16 & 10.33 & 1.93 & $\mathbf{6 . 3}$ \\
& $\mathbf{8 . 2}$ & $\mathbf{1 0 . 3}$ & $\mathbf{6 . 7}$ & $\mathbf{2 0 0 8}$ \\
& \multicolumn{4}{c}{ South Africa } \\
1 & $\mathbf{2 0 0 7}$ & $\mathbf{2 0 0 8}$ & $\mathbf{2 0 0 7}$ & -3.4 \\
2 & 6.1 & 10.6 & 2.01 & 3.66 \\
3 & 7.1 & 12.2 & 2.72 & 0.9 \\
4 & 7.2 & 13.1 & 2.16 & 0.8 \\
Annual & 9 & 9.5 & 2.7 & $\mathbf{3 . 7}$ \\
\hline
\end{tabular}

Notes: CPI variation is the change from one quarter with respect to the same quarter in the previous year. Change in GDP is the variation with respect to January of each year (so that the cumulated variation in the first quarter is from January 1st to March 30th- and the annual variation is from January 1st to December 31th).

Sources: World Bank, Insituto Nacional de Estatística (INE) and Statistics South Africa. 
Now (Aug-08)

1 year earlier (Aug. 6 months earlier (Jan-

07)

08)- placebo period

Total

No intention

66.89

63.29

62.91

64.36

Weak Intention

9.05

10.79

12.35

10.73

11.31

11.84

11.63

11.59

Surely

12.75

14.08

13.11

13.31

Total

100

100

100

100 


\begin{tabular}{cccc} 
Now (Aug-08) & $\begin{array}{c}\text { 1 year earlier } \\
\text { (Aug-07) }\end{array}$ & $\begin{array}{c}\text { 6 months earlier } \\
\text { (Jan-08) } \\
\text { placebo period }\end{array}$ & Total \\
\hline \multicolumn{4}{c}{ Hh sub-sample with small household size (<4) } \\
\hline 73.31 & 74.48 & 73.62 & 73.81 \\
9.63 & 5.39 & 9.07 & 8.03 \\
6.59 & 9.34 & 7.77 & 7.9 \\
10.47 & 10.79 & 9.54 & 10.27 \\
\multicolumn{4}{r}{} \\
\hline 50.96 & Hh sub-sample with big household size (>7) \\
18.5 & 50.98 & 60.22 & 54.06 \\
13.87 & 17.59 & 10.6 & 15.56 \\
16.67 & 13.89 & 13.66 & 13.81 \\
& 17.53 & 15.52 & 16.57 \\
\hline
\end{tabular}

No intention

Weak Intention

Strong intention

Surely

Hh sub-sample with big household size $(>7)$

No intention

Weak Intention

Strong intention

Surely

16.67

13.89

15.52

16.57 
Table 5- Migration intentions over time by hh group membership/ social network (\%)

\begin{tabular}{|c|c|c|c|c|}
\hline & Now (Aug-08) & $\begin{array}{c}1 \text { year earlier } \\
\text { (Aug-07) }\end{array}$ & $\begin{array}{c}6 \text { months earlier } \\
\text { (Jan-08)- placebo } \\
\text { period }\end{array}$ & Total \\
\hline & \multicolumn{4}{|c|}{ Hh sub-sample with no group membership } \\
\hline No intention & 61.82 & 61.67 & 66.89 & 63.46 \\
\hline Weak Intention & 10.93 & 12.32 & 8.84 & 10.7 \\
\hline Strong intention & 10.92 & 11.37 & 9.97 & 10.75 \\
\hline \multirow[t]{2}{*}{ Surely } & 16.33 & 14.64 & 14.31 & 15.09 \\
\hline & \multicolumn{4}{|c|}{ Hh sub-sample with group membership } \\
\hline No intention & 67.34 & 66.3 & 66.92 & 66.85 \\
\hline Weak Intention & 10.41 & 12.41 & 9.64 & 10.82 \\
\hline Strong intention & 14.37 & 12.36 & 14.99 & 13.91 \\
\hline Surely & 7.88 & 8.93 & 8.46 & 8.42 \\
\hline Total & 100 & 100 & 100 & 100 \\
\hline
\end{tabular}


Table 6: Summary statistics of households level controls

\begin{tabular}{lccccc}
\hline Variable & Obs & Mean & Std. Dev. & Min & Max \\
\hline & & & & & \\
Female HH head (\%) & 2706 & 0.39 & 0.49 & 0 & 1 \\
Age of HH head & 2706 & 45.76 & 16.63 & 16 & 99 \\
HH size & 2706 & 5.41 & 3.03 & 1 & 15 \\
Number of Female in HH & 2706 & 2.75 & 1.80 & 0 & 11 \\
Number of children in HH (<5 years) & 2706 & 0.66 & 0.88 & 0 & 6 \\
Average HH years of schooling & 2706 & 4.04 & 2.81 & 0 & 14 \\
HH head-occupation-farmer (\%) & 2706 & 0.36 & 0.48 & 0 & 1 \\
Wealth Index & 2706 & 0.00 & 2.15 & -3.7 & 7.3 \\
& & & & & \\
HH migration experience (current) & 2706 & 0.39 & 0.49 & 0 & 1 \\
HH migration experience (past) & 2706 & 0.26 & 0.44 & 0 & 1 \\
Being informed about attacks in SA & 2706 & 0.95 & 0.21 & 0 & 1 \\
Ronga & 2706 & 0.13 & 0.34 & 0 & 1 \\
Chope & 2706 & 0.01 & 0.09 & 0 & 1 \\
Changana & 2706 & 0.83 & 0.37 & 0 & 1 \\
Other ethnicity & 2706 & 0.03 & 0.16 & 0 & 1 \\
No religion & 2706 & 0.12 & 0.32 & 0 & 1 \\
Catholic & 2706 & 0.17 & 0.38 & 0 & 1 \\
Spiritism & 2706 & 0.44 & 0.50 & 0 & 1 \\
HH in urban area (\%) & 2706 & 0.37 & 0.48 & 0 & 1 \\
Community varaibles & & & & & \\
Paving Rosad & 2706 & 0.11 & 0.32 & 0 & 1 \\
Primary school & 2706 & 0.66 & 0.48 & 0 & 1 \\
Bank & 2706 & 0.04 & 0.19 & 0 & 1 \\
Market & 2706 & 0.39 & 0.49 & 0 & 1 \\
Health center & 2706 & 0.20 & 0.40 & 0 & 1 \\
\hline
\end{tabular}


Table 7: Probit marginal effects of positive migration intentions

\begin{tabular}{|c|c|c|c|c|c|c|}
\hline & (1) & $(2)$ & (3) & (4) & (5) & (6) \\
\hline Tdummy (Aug 08) (b) & $\begin{array}{c}-0.040 * * * \\
(0.015)\end{array}$ & $\begin{array}{c}-0.039 * * \\
(0.016)\end{array}$ & $\begin{array}{c}-0.041^{* *} \\
(0.018)\end{array}$ & $\begin{array}{c}-0.043^{* *} \\
(0.019)\end{array}$ & $\begin{array}{c}-0.046^{* *} \\
(0.019)\end{array}$ & $\begin{array}{c}-0.046^{* *} \\
(0.019)\end{array}$ \\
\hline Tdummy (Jan 08)- placebo & & $\begin{array}{c}0.003 \\
(0.009)\end{array}$ & $\begin{array}{c}0.003 \\
(0.010)\end{array}$ & $\begin{array}{c}0.003 \\
(0.011)\end{array}$ & $\begin{array}{c}0.004 \\
(0.011)\end{array}$ & $\begin{array}{c}0.004 \\
(0.011)\end{array}$ \\
\hline HH migration experience (current) & & & & $\begin{array}{c}0.240 * * * \\
(0.039)\end{array}$ & $\begin{array}{c}0.262 * * * \\
(0.041)\end{array}$ & $\begin{array}{c}0.263 * * * \\
(0.041)\end{array}$ \\
\hline HH migration experience (past) & & & & $\begin{array}{c}0.163 * * * \\
(0.047)\end{array}$ & $\begin{array}{c}0.189 * * * \\
(0.048)\end{array}$ & $\begin{array}{c}0.188 * * * \\
(0.048)\end{array}$ \\
\hline Seasonal migration experience & & & & $\begin{array}{l}-0.010 \\
(0.083)\end{array}$ & $\begin{array}{l}-0.027 \\
(0.086)\end{array}$ & $\begin{array}{l}-0.033 \\
(0.085)\end{array}$ \\
\hline Female HH head & & & $\begin{array}{l}-0.073 * \\
(0.039)\end{array}$ & $\begin{array}{c}-0.081 * * \\
(0.039)\end{array}$ & $\begin{array}{l}-0.076^{*} \\
(0.041)\end{array}$ & $\begin{array}{l}-0.071 * \\
(0.040)\end{array}$ \\
\hline Age of $\mathrm{HH}$ head & & & $\begin{array}{l}-0.000 \\
(0.005)\end{array}$ & $\begin{array}{c}0.004 \\
(0.005)\end{array}$ & $\begin{array}{c}0.003 \\
(0.006)\end{array}$ & $\begin{array}{c}0.003 \\
(0.006)\end{array}$ \\
\hline Age of $\mathrm{HH}$ head squared & & & $\begin{array}{l}-0.000 \\
(0.000)\end{array}$ & $\begin{array}{l}-0.000 * \\
(0.000)\end{array}$ & $\begin{array}{c}-0.000 \\
(0.000)\end{array}$ & $\begin{array}{c}-0.000 \\
(0.000)\end{array}$ \\
\hline HH size (including migrants) & & & $\begin{array}{c}0.035^{* * * *} \\
(0.011)\end{array}$ & $\begin{array}{c}0.016 \\
(0.011)\end{array}$ & $\begin{array}{c}0.023^{* *} \\
(0.011)\end{array}$ & $\begin{array}{c}0.023^{* *} \\
(0.011)\end{array}$ \\
\hline Number of females in the $\mathrm{HH}$ & & & $\begin{array}{c}0.001 \\
(0.017)\end{array}$ & $\begin{array}{c}0.018 \\
(0.017)\end{array}$ & $\begin{array}{c}0.018 \\
(0.017)\end{array}$ & $\begin{array}{c}0.018 \\
(0.017)\end{array}$ \\
\hline Number of children in the $\mathrm{HH}$ (<5years-old) & & & $\begin{array}{l}-0.011 \\
(0.026)\end{array}$ & $\begin{array}{l}-0.016 \\
(0.025)\end{array}$ & $\begin{array}{c}-0.022 \\
(0.026)\end{array}$ & $\begin{array}{l}-0.020 \\
(0.026)\end{array}$ \\
\hline Average hh years of schooling & & & $\begin{array}{l}-0.003 \\
(0.021)\end{array}$ & $\begin{array}{c}-0.023 \\
(0.021)\end{array}$ & $\begin{array}{c}-0.054^{* *} \\
(0.022)\end{array}$ & $\begin{array}{c}-0.053^{* *} \\
(0.022)\end{array}$ \\
\hline Average hh years of schooling squared & & & $\begin{array}{l}-0.001 \\
(0.002)\end{array}$ & $\begin{array}{c}0.001 \\
(0.002)\end{array}$ & $\begin{array}{c}0.003 \\
(0.002)\end{array}$ & $\begin{array}{c}0.003 \\
(0.002)\end{array}$ \\
\hline HH head occupation- farmer & & & $\begin{array}{c}-0.142^{* * *} \\
(0.039)\end{array}$ & $\begin{array}{c}-0.143^{* * *} \\
(0.039)\end{array}$ & $\begin{array}{c}-0.167^{* * *} \\
(0.042)\end{array}$ & $\begin{array}{c}-0.166^{* * *} \\
(0.042)\end{array}$ \\
\hline Wealth index (c) & & & $\begin{array}{c}0.034^{* * *} \\
(0.011)\end{array}$ & $\begin{array}{c}0.031 * * * \\
(0.011)\end{array}$ & $\begin{array}{c}0.029 * * \\
(0.013)\end{array}$ & $\begin{array}{l}0.028 * * \\
(0.013)\end{array}$ \\
\hline Wealth index squared & & & $\begin{array}{l}-0.006^{*} \\
(0.003)\end{array}$ & $\begin{array}{c}-0.007^{* *} \\
(0.003)\end{array}$ & $\begin{array}{l}-0.006^{*} \\
(0.003)\end{array}$ & $\begin{array}{l}-0.005 \\
(0.003)\end{array}$ \\
\hline Urban area & & & $\begin{array}{l}-0.075^{*} \\
(0.041)\end{array}$ & $\begin{array}{c}-0.079 * \\
(0.041)\end{array}$ & $\begin{array}{c}0.119 \\
(0.296)\end{array}$ & $\begin{array}{c}0.128 \\
(0.297)\end{array}$ \\
\hline Being informed about attacks in SA & & & & & & $\begin{array}{c}-0.104 \\
(0.103)\end{array}$ \\
\hline Ethincity, religion controls & yes & yes & yes & yes & yes & yes \\
\hline Community controls & no & no & yes & yes & no & no \\
\hline Community Fe & no & no & no & no & yes & yes \\
\hline Observations & 2701 & 2701 & 2701 & 2701 & 2701 & 2701 \\
\hline
\end{tabular}

Robust standard errors clustered at housheold levels in parentheses. ${ }^{* * *} \mathrm{p}<0.01,{ }^{* *} \mathrm{p}<0.05,{ }^{*} \mathrm{p}<0.1$

Notes: (a) The dependent variable is a discrete variable equal to 1 if the household respondent reports a positive intention of emigration ( 0 otherwise). (b) The reference category is August 2007. (c) The wealth index is the first component of a principal component analysis, which uses dwelling conditions and assets ownership of the HH. (d) Columns 5-6 show estimates with fixed effects at the community level. (e) Further household chacteristics include ethnic group (Changana, Ronga, Chope, Other minorities) and religion (Catholic, Presbyterian, Methodist, Anglican, Baptist, Adventist, Islam, Tradition spiritsm, other). (f) Community level characteristics include th quality of roads, school, health facilities, formal bank and market availability. 
Table 8: Heterogeneous probit models- marginal effects (c)

\begin{tabular}{lcc}
\hline & Panel A: HH size & \\
\hline & Low $(<4)$ & High (>6) \\
\cline { 2 - 3 } Tdummy (Aug 08)b & 0.005 & $-0.109^{* * *}$ \\
& $(0.028)$ & $(0.034)$ \\
Tdummy (Jan 08) & 0.004 & 0.011 \\
& $(0.017)$ & $(0.020)$ \\
HH migration experience (current) & $0.186^{* * *}$ & $0.266^{* * *}$ \\
& $(0.063)$ & $(0.063)$ \\
HH migration experience (past) & $0.212^{* * *}$ & $0.149^{* *}$ \\
& $(0.066)$ & $(0.073)$ \\
HH and community controls & yes & yes \\
Observations & 1398 & 905 \\
\hline
\end{tabular}

Panel B: N.of children ( $<15$ years old)

\begin{tabular}{lcc}
\hline & Low $(<2)$ & High $(>4)$ \\
\cline { 2 - 3 } Tdummy (Aug 08)b & -0.003 & $-0.111^{* * *}$ \\
Tdummy (Jan 08) & $(0.029)$ & $(0.035)$ \\
& -0.016 & 0.005 \\
HH migration experience (current) & $(0.016)$ & $(0.018)$ \\
& $0.178^{* * *}$ & $0.203^{* * *}$ \\
HH migration experience (past) & $(0.062)$ & $(0.059)$ \\
& 0.067 & 0.100 \\
HH and community controls & $(0.071)$ & $(0.070)$ \\
Observations & yes & yes \\
\hline
\end{tabular}

\begin{tabular}{lcc}
\hline & Panel C: N.of females & High $(>4)$ \\
\cline { 2 - 3 } Tdummy (Aug 08)b & -0.013 & $-0.136^{* * *}$ \\
& $(0.025)$ & $(0.041)$ \\
Tdummy (Jan 08) & -0.010 & 0.017 \\
& $(0.012)$ & $(0.021)$ \\
HH migration experience (current) & $0.212^{* * *}$ & $0.331^{* * *}$ \\
& $(0.062)$ & $(0.070)$ \\
HH migration experience (past) & $0.214^{* * *}$ & 0.046 \\
& $(0.064)$ & $(0.081)$ \\
HH and community controls & yes & yes \\
Observations & 1383 & 733 \\
\hline Robust standard errors clustered at household level in parentheses; ${ }^{* * *} \mathrm{p}<0.01,{ }^{* *} \mathrm{p}<0.05, * \mathrm{p}<0.1$.
\end{tabular}

Notes: (a) The dependent variable is a discrete variable equal to 1 if the household respondent reports a positive intention of emigration (0 otherwise). (b) Control variables are: Seasonal migration experience, Female $\mathrm{HH}$ head, Age of HH head, Age of HH head squared, HH size, Number of females in the HH, Number of children in the HH (<5years-old), Average hh years of schooling, Average hh years of schooling squared, HH head occupation- farmer, Wealth index, Wealth index squared, Ethnicity, Religion, Urban area, Community characteristics (paved-road, primary school, Bank, market, health facility). (c) We distinguish between 'low' and 'high' sub-groups by using always the first two and the last two quantiles of all demographic variable distribution. 
Table 9 Heterogeneous probit models- marginal effects

\begin{tabular}{|c|c|c|c|c|}
\hline \multicolumn{5}{|c|}{ Panel B: Community group membership } \\
\hline & \multicolumn{2}{|c|}{ NO group member } & \multicolumn{2}{|c|}{ Group member } \\
\hline Tdummy (Aug 08)b & $\begin{array}{l}-0.061^{* * *} \\
(0.020)\end{array}$ & $\begin{array}{c}-0.061^{* * *} \\
(0.021)\end{array}$ & $\begin{array}{l}-0.008 \\
(0.041)\end{array}$ & $\begin{array}{l}-0.002 \\
(0.041)\end{array}$ \\
\hline Tdummy (Jan 08) & & $\begin{array}{l}-0.002 \\
(0.014)\end{array}$ & & $\begin{array}{c}0.013 \\
(0.019)\end{array}$ \\
\hline HH migration experience (current) & $\begin{array}{c}0.269 * * * \\
(0.046)\end{array}$ & $\begin{array}{c}0.269 * * * \\
(0.046)\end{array}$ & $\begin{array}{c}0.134 * \\
(0.070)\end{array}$ & $\begin{array}{l}0.134 * \\
(0.070)\end{array}$ \\
\hline HH migration experience (past) & $\begin{array}{c}0.193 * * * \\
(0.060)\end{array}$ & $\begin{array}{c}0.193 * * * \\
(0.060)\end{array}$ & $\begin{array}{c}0.093 \\
(0.077)\end{array}$ & $\begin{array}{c}0.093 \\
(0.077)\end{array}$ \\
\hline $\begin{array}{l}\mathrm{HH} \text { and community controls } \\
\text { Observations }\end{array}$ & $\begin{array}{c}\text { yes } \\
1996\end{array}$ & $\begin{array}{c}\text { yes } \\
1996\end{array}$ & $\begin{array}{l}\text { yes } \\
684\end{array}$ & $\begin{array}{l}\text { yes } \\
684\end{array}$ \\
\hline \multicolumn{5}{|c|}{ Panel B: Informal social networks } \\
\hline & \multicolumn{2}{|c|}{ NO inter-hh exchange } & \multicolumn{2}{|c|}{ Inter-hh exchange } \\
\hline Tdummy (Aug 08) & $\begin{array}{c}-0.073^{* * *} \\
(0.019)\end{array}$ & $\begin{array}{c}-0.069 * * * \\
(0.021)\end{array}$ & $\begin{array}{c}0.026 \\
(0.042)\end{array}$ & $\begin{array}{c}0.021 \\
(0.042)\end{array}$ \\
\hline HH migration experience (current and past) & & $\begin{array}{c}0.007 \\
(0.014)\end{array}$ & & $\begin{array}{l}-0.008 \\
(0.017)\end{array}$ \\
\hline Migr experience before the war & $\begin{array}{c}0.279 * * * \\
(0.045)\end{array}$ & $\begin{array}{c}0.280^{* * *} \\
(0.045)\end{array}$ & $\begin{array}{c}0.101 \\
(0.081)\end{array}$ & $\begin{array}{c}0.101 \\
(0.081)\end{array}$ \\
\hline Tdummy (Jan 08)- placebo & $\begin{array}{c}0.209 * * * \\
(0.058)\end{array}$ & $\begin{array}{c}0.209 * * * \\
(0.058)\end{array}$ & $\begin{array}{c}0.087 \\
(0.077)\end{array}$ & $\begin{array}{c}0.087 \\
(0.077)\end{array}$ \\
\hline $\begin{array}{l}\mathrm{HH} \text { and community controls } \\
\text { Observations }\end{array}$ & $\begin{array}{c}\text { yes } \\
1799\end{array}$ & $\begin{array}{c}\text { yes } \\
1799\end{array}$ & $\begin{array}{l}\text { yes } \\
884\end{array}$ & $\begin{array}{l}\text { yes } \\
884\end{array}$ \\
\hline
\end{tabular}

Robust standard errors clustered at household level in parentheses; *** $\mathrm{p}<0.01, * * \mathrm{p}<0.05,{ }^{*} \mathrm{p}<0.1$.

Notes: (a) The dependent variable is a discrete variable equal to 1 if the household respondent reports a positive intention of emigration (0 otherwise). (b) Control vars are as in Table 8. (c) Group membership is a binary variable equal to 1 if any member of the household has participated in any of the following community group: ROSCAs, bank, farmers association, burials association, ONGs actions, selfhelp religious group, political group, women group, civic group, migrant's group, young group, others. (d) Give or receive a binary viariable equal to 1 if the $\mathrm{HH}$ has given or received products or services in the last month from at least one of the following key persons in the community: traditional leader, elected leader, teacher, agricultural agent, priest, neighbours, health provider, healer, employer. 


\begin{tabular}{|c|c|c|c|c|}
\hline \multicolumn{5}{|c|}{ Panel A: HH size } \\
\hline & \multicolumn{2}{|c|}{ Low $(<4)$} & \multicolumn{2}{|c|}{ High (>7) } \\
\hline & $\begin{array}{l}\text { No group } \\
\text { member }\end{array}$ & Group member & No group member & Group member \\
\hline \multirow[t]{2}{*}{ Tdummy (Aug 08)b } & -0.018 & 0.058 & $-0.141 * * *$ & -0.075 \\
\hline & $(0.031)$ & $(0.055)$ & $(0.041)$ & $(0.072)$ \\
\hline \multirow[t]{2}{*}{ Tdummy (Jan 08) } & 0.001 & 0.012 & 0.000 & 0.028 \\
\hline & $(0.021)$ & $(0.028)$ & $(0.027)$ & $(0.036)$ \\
\hline \multirow[t]{2}{*}{ HH migration experience (current) } & $0.210^{* * *}$ & -0.063 & $0.282 * * *$ & $0.307^{* *}$ \\
\hline & $(0.078)$ & $(0.077)$ & $(0.079)$ & $(0.129)$ \\
\hline \multirow[t]{2}{*}{ HH migration experience (past) } & $0.273^{* * *}$ & 0.105 & 0.150 & 0.104 \\
\hline & $(0.086)$ & $(0.095)$ & $(0.094)$ & $(0.123)$ \\
\hline $\mathrm{HH}$ and community controls & yes & yes & yes & yes \\
\hline Observations & 1101 & 288 & 614 & 282 \\
\hline \multicolumn{5}{|c|}{ Panel B: N children (>15 years old) } \\
\hline & \multicolumn{2}{|c|}{ Low $(<2)$} & \multicolumn{2}{|c|}{ High (>4) } \\
\hline & $\begin{array}{l}\text { No group } \\
\text { member }\end{array}$ & Group member & No group member & Group member \\
\hline \multirow[t]{2}{*}{ Tdummy (Aug 08)b } & -0.030 & 0.103 & $-0.145^{* * *}$ & -0.061 \\
\hline & $(0.029)$ & $(0.091)$ & $(0.038)$ & $(0.083)$ \\
\hline \multirow[t]{2}{*}{ Tdummy (Jan 08) } & -0.019 & -0.007 & -0.005 & 0.022 \\
\hline & $(0.016)$ & $(0.044)$ & $(0.025)$ & $(0.027)$ \\
\hline \multirow[t]{2}{*}{ HH migration experience (current) } & $0.274 * * *$ & $-0.275^{* * *}$ & $0.248^{* * *}$ & 0.178 \\
\hline & $(0.069)$ & $(0.085)$ & $(0.076)$ & $(0.113)$ \\
\hline \multirow[t]{2}{*}{ HH migration experience (past) } & 0.048 & $-0.157 * *$ & $0.201^{* *}$ & -0.157 \\
\hline & $(0.082)$ & $(0.077)$ & $(0.089)$ & $(0.130)$ \\
\hline $\mathrm{HH}$ and community controls & yes & yes & yes & yes \\
\hline \multirow[t]{4}{*}{ Observations } & 973 & 237 & 662 & 276 \\
\hline & \multicolumn{4}{|c|}{ Panel C: $\mathbf{N}$ females } \\
\hline & \multicolumn{2}{|c|}{ Low $(<4)$} & \multicolumn{2}{|c|}{ High (>6) } \\
\hline & $\begin{array}{l}\text { No group } \\
\text { member }\end{array}$ & Group member & No group member & Group member \\
\hline \multirow[t]{2}{*}{ Tdummy (Aug 08)b } & -0.040 & 0.060 & $-0.166^{* * *}$ & -0.106 \\
\hline & $(0.026)$ & $(0.068)$ & $(0.050)$ & $(0.081)$ \\
\hline \multirow[t]{2}{*}{ Tdummy (Jan 08) } & -0.020 & 0.012 & 0.008 & 0.027 \\
\hline & $(0.014)$ & $(0.027)$ & $(0.029)$ & $(0.031)$ \\
\hline \multirow[t]{2}{*}{ HH migration experience (current) } & $0.277 * * *$ & -0.134 & $0.372 * * *$ & $0.535 * * *$ \\
\hline & $(0.073)$ & $(0.095)$ & $(0.081)$ & $(0.133)$ \\
\hline \multirow[t]{2}{*}{ HH migration experience (past) } & $0.228 * * *$ & $0.195 *$ & 0.042 & 0.213 \\
\hline & $(0.087)$ & $(0.116)$ & $(0.106)$ & $(0.156)$ \\
\hline $\mathrm{HH}$ and community controls & yes & yes & yes & yes \\
\hline Observations & 1044 & 324 & 514 & 213 \\
\hline
\end{tabular}

Robust standard errors clustered at household level in parentheses; *** $\mathrm{p}<0.01, * * \mathrm{p}<0.05,{ }^{*} \mathrm{p}<0.1$.

Notes: (a) The dependent variable is a discrete variable equal to 1 if the household respondent reports a positive intention of emigration (0 otherwise). (b) Control vars are as in Table 8. (c) We distinguish between 'low' and 'high' sub-groups by using always the first two and the last two quantiles of all demographic variable distribution. 


\section{Table 11- Occupation at destination (\%)}

Farm worker

Current migrants

Non-farm worker/employee

1.23

Self-employed

5.19

Informal worker (trader, street vendor)

2.31

12.68

Student

4.12

Domestic worker

Miner

15.75

Skilled worker

7.22

Unkilled worker

15.2

Unknown

21.02

Unemployed

4.08

Other

8.2

Type of contract of current migrants at destination (\%)

\begin{tabular}{lc}
\hline Permanent & 20.06 \\
Temporary & 44.78 \\
Seasonal & 6.74 \\
NR & 28.41 \\
Total & 100 \\
\hline
\end{tabular}


Table 12: Source of help on the migration process

\section{Current Migrants Past Migrants}

Family in Mozambique

33.75

33.89

Family abroad

12.97

17.94

Friends in Mozambique

4.53

2.99

Friends abroad

5.16

1.33

Previous Experience

34.69

24.58

Neighbords

0.78

0.66

Government

0.78

3.32

Recruitment agency

4.69

11.63

Other

2.66

3.65 


\section{APPENDIX}

Table A1: Heterogeneous probit models- marginal effects (c)

\begin{tabular}{|c|c|c|}
\hline \multicolumn{3}{|c|}{ Panel C: N.of 'adult children' (>15 years old) } \\
\hline & Low $(<1)$ & High $(>2)$ \\
\hline Tdummy (Aug 08)b & $\begin{array}{l}-0.008 \\
(0.026)\end{array}$ & $\begin{array}{c}-0.117 * * * \\
(0.035)\end{array}$ \\
\hline Tdummy (Jan 08) & $\begin{array}{c}0.019 \\
(0.016)\end{array}$ & $\begin{array}{l}-0.009 \\
(0.021)\end{array}$ \\
\hline HH migration experience (current) & $\begin{array}{c}0.220 * * * \\
(0.056)\end{array}$ & $\begin{array}{c}0.292 * * * \\
(0.072)\end{array}$ \\
\hline HH migration experience (past) & $\begin{array}{c}0.179 * * * \\
(0.060)\end{array}$ & $\begin{array}{c}0.172 * * \\
(0.088)\end{array}$ \\
\hline \multicolumn{3}{|l|}{$\mathrm{HH}$ and community controls } \\
\hline Observations & 1509 & 763 \\
\hline \multicolumn{3}{|c|}{ Panel D: N.of male 'adult children' (>15 years old) } \\
\hline & Low $(<0)$ & High (>2) \\
\hline Tdummy (Aug 08)b & $\begin{array}{c}-0.011 \\
(0.023)\end{array}$ & $\begin{array}{c}-0.112 * * * \\
(0.033)\end{array}$ \\
\hline Tdummy (Jan 08) & $\begin{array}{c}0.015 \\
(0.014)\end{array}$ & $\begin{array}{l}-0.019 \\
(0.017)\end{array}$ \\
\hline HH migration experience (current) & $\begin{array}{c}0.238 * * * \\
(0.051)\end{array}$ & $\begin{array}{c}0.214^{* * *} \\
(0.067)\end{array}$ \\
\hline HH migration experience (past) & $\begin{array}{c}0.183 * * * \\
(0.057)\end{array}$ & $\begin{array}{l}0.142 * \\
(0.086)\end{array}$ \\
\hline $\mathrm{HH}$ and community controls & & \\
\hline Observations & 1754 & 947 \\
\hline
\end{tabular}


Table A2. Probit model of positive migration intentions - interaction effects with demographics

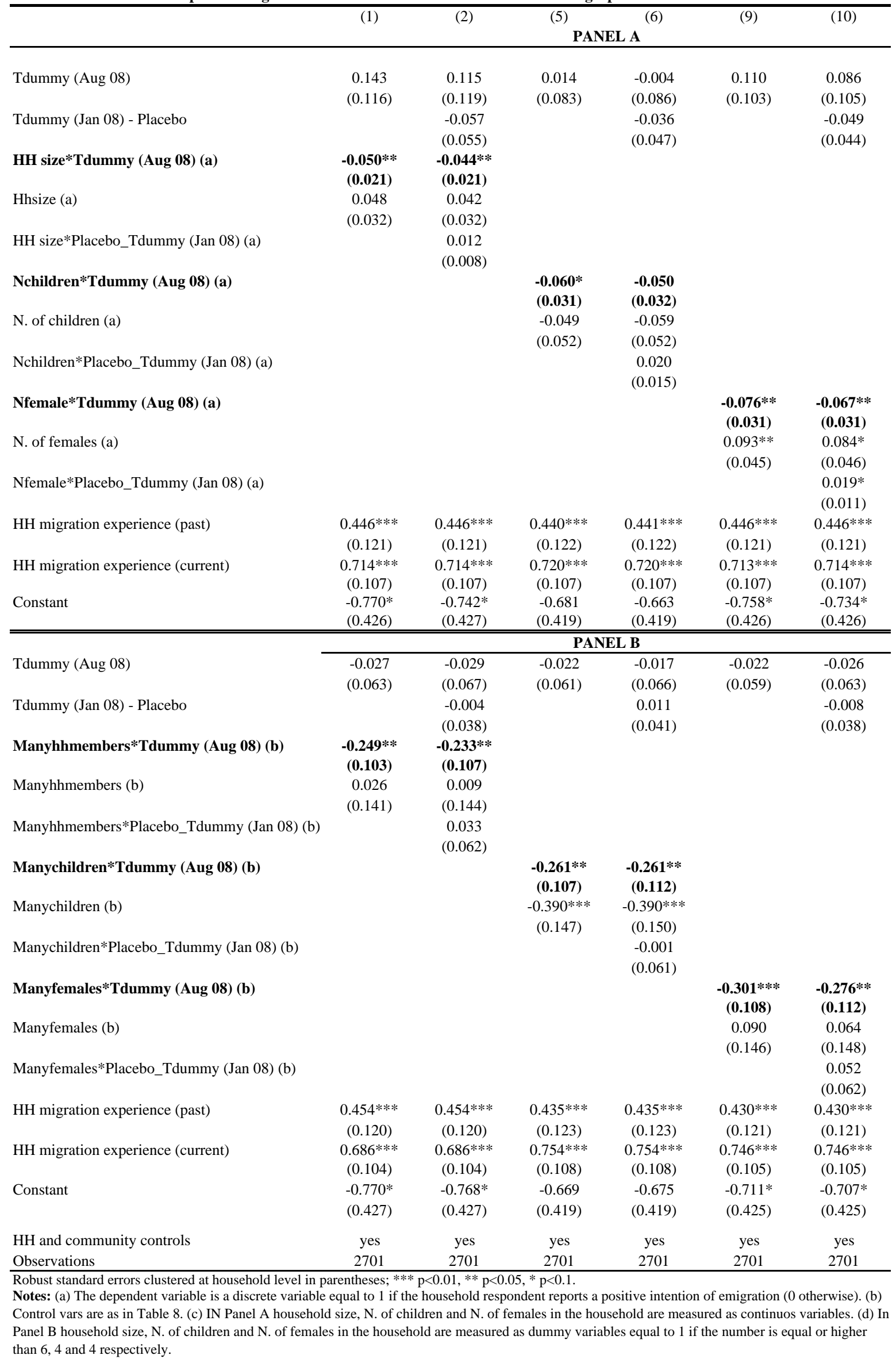


Table A3. Probit model of positive migration intentions - interaction effects with demographics

\begin{tabular}{|c|c|c|c|c|c|c|}
\hline & (1) & (2) & (5) & (6) & (9) & $(10)$ \\
\hline & \multicolumn{6}{|c|}{ PANEL A } \\
\hline Tdummy (Aug 08) & $\begin{array}{c}0.143 \\
(0.121)\end{array}$ & $\begin{array}{c}0.112 \\
(0.124)\end{array}$ & $\begin{array}{c}0.008 \\
(0.087)\end{array}$ & $\begin{array}{l}-0.011 \\
(0.090)\end{array}$ & $\begin{array}{c}0.112 \\
(0.109)\end{array}$ & $\begin{array}{c}0.088 \\
(0.111)\end{array}$ \\
\hline Tdummy (Jan 08) - Placebo & & $\begin{array}{c}-0.063 \\
(0.058)\end{array}$ & & $\begin{array}{l}-0.038 \\
(0.050)\end{array}$ & & $\begin{array}{c}-0.048 \\
(0.048)\end{array}$ \\
\hline HH size*Tdummy (Aug 08) (a) & $\begin{array}{c}-0.052 * * \\
(0.021)\end{array}$ & $\begin{array}{c}-0.045 * * \\
(0.021)\end{array}$ & & & & \\
\hline Hhsize (a) & $\begin{array}{l}0.072 * * \\
(0.033)\end{array}$ & $\begin{array}{l}0.066^{*} \\
(0.034)\end{array}$ & & & & \\
\hline HH size*Placebo_Tdummy (Jan 08) (a) & & $\begin{array}{c}0.014 \\
(0.009)\end{array}$ & & & & \\
\hline Nchildren*Tdummy (Aug 08) (a) & & & $\begin{array}{c}-0.062 * \\
(0.033)\end{array}$ & $\begin{array}{c}-0.052 \\
(0.034)\end{array}$ & & \\
\hline N. of children (a) & & & $\begin{array}{c}-0.069 \\
(0.052)\end{array}$ & $\begin{array}{l}-0.080 \\
(0.052)\end{array}$ & & \\
\hline Nchildren*Placebo_Tdummy (Jan 08) (a) & & & & $\begin{array}{c}0.022 \\
(0.016)\end{array}$ & & \\
\hline Nfemale*Tdummy (Aug 08) (a) & & & & & $\begin{array}{c}-0.080 * * \\
(0.032)\end{array}$ & $\begin{array}{c}-0.071 * * \\
(0.033)\end{array}$ \\
\hline N. of females (a) & & & & & $\begin{array}{c}0.077 \\
(0.050)\end{array}$ & $\begin{array}{c}0.068 \\
(0.050)\end{array}$ \\
\hline Nfemale*Placebo_Tdummy (Jan 08) (a) & & & & & & $\begin{array}{c}0.019 \\
(0.012)\end{array}$ \\
\hline HH migration experience (past) & $\begin{array}{c}0.521^{* * *} \\
(0.126)\end{array}$ & $\begin{array}{c}0.521^{* * *} \\
(0.126)\end{array}$ & $\begin{array}{c}0.514 * * * \\
(0.126)\end{array}$ & $\begin{array}{c}0.515^{* * *} \\
(0.126)\end{array}$ & $\begin{array}{c}0.521^{* * *} \\
(0.125)\end{array}$ & $\begin{array}{c}0.521 * * * \\
(0.125)\end{array}$ \\
\hline HH migration experience (current) & $\begin{array}{c}0.807 * * * \\
(0.110)\end{array}$ & $\begin{array}{c}0.807^{* * *} \\
(0.110)\end{array}$ & $\begin{array}{c}0.677 * * * \\
(0.114)\end{array}$ & $\begin{array}{c}0.677 * * * \\
(0.114)\end{array}$ & $\begin{array}{c}0.716^{* * *} \\
(0.112)\end{array}$ & $\begin{array}{c}0.716^{* * *} \\
(0.112)\end{array}$ \\
\hline Constant & $\begin{array}{c}-0.024 \\
(0.503) \\
\end{array}$ & $\begin{array}{c}0.008 \\
(0.503) \\
\end{array}$ & $\begin{array}{c}0.077 \\
(0.492) \\
\end{array}$ & $\begin{array}{c}0.097 \\
(0.492) \\
\end{array}$ & $\begin{array}{c}0.004 \\
(0.500) \\
\end{array}$ & $\begin{array}{c}0.028 \\
(0.501) \\
\end{array}$ \\
\hline & & & PA & L B & & \\
\hline Tdummy (Aug 08) & $\begin{array}{c}-0.033 \\
(0.067)\end{array}$ & $\begin{array}{c}-0.036 \\
(0.071)\end{array}$ & $\begin{array}{c}-0.028 \\
(0.065)\end{array}$ & $\begin{array}{c}-0.021 \\
(0.070)\end{array}$ & $\begin{array}{c}-0.027 \\
(0.062)\end{array}$ & $\begin{array}{c}-0.031 \\
(0.066)\end{array}$ \\
\hline Tdummy (Jan 08) - Placebo & & $\begin{array}{c}-0.006 \\
(0.040)\end{array}$ & & $\begin{array}{c}0.013 \\
(0.044)\end{array}$ & & $\begin{array}{c}-0.008 \\
(0.041)\end{array}$ \\
\hline Manyhhmembers*Tdummy (Aug 08) (b) & $\begin{array}{c}-0.259 * * \\
(0.109)\end{array}$ & $\begin{array}{c}-0.239 * * \\
(0.113)\end{array}$ & & & & \\
\hline Manyhhmembers (b) & $\begin{array}{c}0.063 \\
(0.145)\end{array}$ & $\begin{array}{c}0.043 \\
(0.149)\end{array}$ & & & & \\
\hline Manyhhmembers*Placebo_Tdummy (Jan 08) (b) & & $\begin{array}{c}0.040 \\
(0.066)\end{array}$ & & & & \\
\hline Manychildren*Tdummy (Aug 08) (b) & & & $\begin{array}{c}-0.277^{* *} \\
(0.115)\end{array}$ & $\begin{array}{c}-0.277^{* *} \\
(0.120)\end{array}$ & & \\
\hline Manychildren (b) & & & $\begin{array}{c}-0.475^{* * *} \\
(0.146)\end{array}$ & $\begin{array}{c}-0.475^{* * *} \\
(0.149)\end{array}$ & & \\
\hline Manychildren*Placebo_Tdummy (Jan 08) (b) & & & & $\begin{array}{c}0.000 \\
(0.066)\end{array}$ & & \\
\hline Manyfemales*Tdummy (Aug 08) (b) & & & & & $\begin{array}{c}-0.320 * * * \\
(0.115)\end{array}$ & $\begin{array}{c}-0.293^{* *} \\
(0.120)\end{array}$ \\
\hline Manyfemales (b) & & & & & $\begin{array}{c}0.048 \\
(0.154)\end{array}$ & $\begin{array}{c}0.020 \\
(0.156)\end{array}$ \\
\hline Manyfemales*Placebo_Tdummy (Jan 08) (b) & & & & & & $\begin{array}{c}0.056 \\
(0.067)\end{array}$ \\
\hline HH migration experience (past) & $\begin{array}{c}0.533 * * * \\
(0.125)\end{array}$ & $\begin{array}{c}0.533 * * * \\
(0.125)\end{array}$ & $\begin{array}{c}0.513^{* * *} \\
(0.126)\end{array}$ & $\begin{array}{c}0.513^{* * *} \\
(0.126)\end{array}$ & $\begin{array}{c}0.510 * * * \\
(0.125)\end{array}$ & $\begin{array}{c}0.510 * * * \\
(0.125)\end{array}$ \\
\hline HH migration experience (current) & $\begin{array}{c}0.772 * * * \\
(0.109)\end{array}$ & $\begin{array}{c}0.773^{* * *} \\
(0.109)\end{array}$ & $\begin{array}{c}0.702^{* * *} \\
(0.112)\end{array}$ & $\begin{array}{c}0.702^{* * *} \\
(0.112)\end{array}$ & $\begin{array}{c}0.700 * * * \\
(0.111)\end{array}$ & $\begin{array}{c}0.700^{* * *} \\
(0.111)\end{array}$ \\
\hline Constant & $\begin{array}{l}-0.047 \\
(0.501)\end{array}$ & $\begin{array}{c}-0.043 \\
(0.501)\end{array}$ & $\begin{array}{c}0.052 \\
(0.497)\end{array}$ & $\begin{array}{c}0.046 \\
(0.497)\end{array}$ & $\begin{array}{c}0.037 \\
(0.500)\end{array}$ & $\begin{array}{c}0.041 \\
(0.502)\end{array}$ \\
\hline HH controls & yes & yes & yes & yes & yes & yes \\
\hline Community fe & yes & yes & yes & yes & yes & yes \\
\hline Observations & 2701 & 2701 & 2701 & 2701 & 2701 & 2701 \\
\hline
\end{tabular}

Robust standard errors clustered at household level in parentheses; *** $\mathrm{p}<0.01,{ }^{* *} \mathrm{p}<0.05,{ }^{*} \mathrm{p}<0.1$.

Notes: (a) The dependent variable is a discrete variable equal to 1 if the household respondent reports a positive intention of emigration ( 0 otherwise). (b

Control vars are as in Table 8 plus community fixed effects. (c) IN Panel A household size, N. of children and N. of females in the household are measured as continuos variables. (d) In Panel B household size, N. of children and N. of females in the household are measured as dummy variables equal to 1 if the number is equal or higher than 6,4 and 4 respectively. 
Table A4. Probit model of positive migration intentions - interaction effects with group participation

(1)

(2)

(3)

(4)

\begin{tabular}{|c|c|c|c|c|}
\hline Tdummy (Aug 08) & $\begin{array}{c}-0.159 * * * \\
(0.054)\end{array}$ & $\begin{array}{c}-0.160 * * * \\
(0.058)\end{array}$ & $\begin{array}{c}-0.173^{* * *} \\
(0.057)\end{array}$ & $\begin{array}{c}-0.174 * * * \\
(0.061)\end{array}$ \\
\hline Tdummy (Jan 08) & & $\begin{array}{l}-0.002 \\
(0.037)\end{array}$ & & $\begin{array}{l}-0.002 \\
(0.040)\end{array}$ \\
\hline Group*Tdummy (Aug 08) & $\begin{array}{c}0.120 \\
(0.124)\end{array}$ & $\begin{array}{c}0.140 \\
(0.127)\end{array}$ & $\begin{array}{c}0.126 \\
(0.131)\end{array}$ & $\begin{array}{c}0.149 \\
(0.135)\end{array}$ \\
\hline Group participation & $\begin{array}{l}-0.207 \\
(0.127)\end{array}$ & $\begin{array}{l}-0.227 * \\
(0.131)\end{array}$ & $\begin{array}{l}-0.166 \\
(0.136)\end{array}$ & $\begin{array}{l}-0.190 \\
(0.141)\end{array}$ \\
\hline Group*Placebo_Tdummy (Aug 08) & & $\begin{array}{c}0.039 \\
(0.064)\end{array}$ & & $\begin{array}{c}0.047 \\
(0.068)\end{array}$ \\
\hline HH migration experience (current) & $\begin{array}{c}0.645^{* * *} \\
(0.107)\end{array}$ & $\begin{array}{c}0.645^{* * *} \\
(0.107)\end{array}$ & $\begin{array}{l}0.712 * * * \\
(0.111)\end{array}$ & $\begin{array}{l}0.712 * * * \\
(0.111)\end{array}$ \\
\hline HH migration experience (past) & $\begin{array}{c}0.466 * * * \\
(0.123)\end{array}$ & $\begin{array}{c}0.466 * * * \\
(0.123)\end{array}$ & $\begin{array}{c}0.534^{* * *} \\
(0.128)\end{array}$ & $\begin{array}{c}0.534^{* * *} \\
(0.128)\end{array}$ \\
\hline $\begin{array}{l}\text { HH and community controls } \\
\text { Community fe }\end{array}$ & $\begin{array}{c}\text { yes } \\
\text { no }\end{array}$ & $\begin{array}{l}\text { yes } \\
\text { no }\end{array}$ & $\begin{array}{l}\text { yes } \\
\text { yes }\end{array}$ & $\begin{array}{l}\text { yes } \\
\text { yes }\end{array}$ \\
\hline Observations & 2701 & 2701 & 2701 & 2701 \\
\hline
\end{tabular}

Robust standard errors clustered at household level in parentheses; *** $\mathrm{p}<0.01,{ }^{* *} \mathrm{p}<0.05,{ }^{*} \mathrm{p}<0.1$.

Notes: (a) The dependent variable is a discrete variable equal to 1 if the household respondent reports a positive intention of

emigration (0 otherwise). (b) Control vars are as in Table 8 (col. 1 and 2) plus community fixed effects (col. 3 and 4). (c) Group is a dummy variable equal to 1 if the housheold is member of one community group. 


\begin{tabular}{|c|c|c|c|c|c|c|c|c|c|c|c|c|}
\hline & (1) & (2) & (3) & (4) & (5) & (6) & (7) & (8) & (9) & (10) & (11) & (12) \\
\hline Tdummy (Aug 08) & $\begin{array}{c}-0.067 \\
(0.068)\end{array}$ & $\begin{array}{c}-0.077 \\
(0.071)\end{array}$ & $\begin{array}{c}-0.048 \\
(0.069)\end{array}$ & $\begin{array}{l}-0.050 \\
(0.073)\end{array}$ & $\begin{array}{c}-0.061 \\
(0.064)\end{array}$ & $\begin{array}{c}-0.075 \\
(0.068)\end{array}$ & $\begin{array}{c}-0.075 \\
(0.072)\end{array}$ & $\begin{array}{c}-0.088 \\
(0.076)\end{array}$ & $\begin{array}{c}-0.056 \\
(0.074)\end{array}$ & $\begin{array}{l}-0.059 \\
(0.078)\end{array}$ & $\begin{array}{c}-0.068 \\
(0.068)\end{array}$ & $\begin{array}{c}-0.084 \\
(0.071)\end{array}$ \\
\hline Tdummy (Jan 08) & $\begin{array}{c}0.009 \\
(0.030)\end{array}$ & $\begin{array}{l}-0.011 \\
(0.045)\end{array}$ & $\begin{array}{c}0.011 \\
(0.031)\end{array}$ & $\begin{array}{c}0.007 \\
(0.048)\end{array}$ & $\begin{array}{c}0.010 \\
(0.030)\end{array}$ & $\begin{array}{c}-0.019 \\
(0.045)\end{array}$ & $\begin{array}{c}0.011 \\
(0.033)\end{array}$ & $\begin{array}{c}-0.015 \\
(0.048)\end{array}$ & $\begin{array}{c}0.014 \\
(0.033)\end{array}$ & $\begin{array}{c}0.007 \\
(0.052)\end{array}$ & $\begin{array}{c}0.012 \\
(0.033)\end{array}$ & $\begin{array}{c}-0.021 \\
(0.049)\end{array}$ \\
\hline Manyhhmembers_Group*Tdummy (Aug 08) & $\begin{array}{c}-0.135 \\
(0.170)\end{array}$ & $\begin{array}{c}-0.098 \\
(0.171)\end{array}$ & & & & & $\begin{array}{c}-0.143 \\
(0.180)\end{array}$ & $\begin{array}{c}-0.098 \\
(0.181)\end{array}$ & & & & \\
\hline Fewhhmembers_Group*Tdummy (Aug 08) & $\begin{array}{c}0.179 \\
(0.168)\end{array}$ & $\begin{array}{c}0.192 \\
(0.177)\end{array}$ & & & & & $\begin{array}{c}0.188 \\
(0.176)\end{array}$ & $\begin{array}{c}0.204 \\
(0.186)\end{array}$ & & & & \\
\hline Manyhhmembers_NOGroup*Tdummy (Aug 08) & $\begin{array}{c}-0.245^{* * *} \\
(0.113)\end{array}$ & $\begin{array}{l}-0.233^{*} \\
(0.120)\end{array}$ & & & & & $\begin{array}{c}-0.254^{* *} \\
(0.120)\end{array}$ & $\begin{array}{l}-0.238^{*} \\
(0.128)\end{array}$ & & & & \\
\hline Manyhhmembers_Group & $\begin{array}{l}-0.308 \\
(0.225)\end{array}$ & $\begin{array}{c}-0.345 \\
(0.228)\end{array}$ & & & & & $\begin{array}{c}-0.292 \\
(0.228)\end{array}$ & $\begin{array}{c}-0.337 \\
(0.232)\end{array}$ & & & & \\
\hline Fewhhmembers_Group & $\begin{array}{l}-0.297^{*} \\
(0.162)\end{array}$ & $\begin{array}{l}-0.310^{*} \\
(0.168)\end{array}$ & & & & & $\begin{array}{c}-0.218 \\
(0.174)\end{array}$ & $\begin{array}{c}-0.234 \\
(0.180)\end{array}$ & & & & \\
\hline Manyhhmembers_NOGroup & $\begin{array}{c}-0.192 \\
(0.178)\end{array}$ & $\begin{array}{c}-0.204 \\
(0.181)\end{array}$ & & & & & $\begin{array}{c}-0.170 \\
(0.185)\end{array}$ & $\begin{array}{c}-0.187 \\
(0.188)\end{array}$ & & & & \\
\hline Manyhhmembers_Group*Placebo_Tdummy & & $\begin{array}{c}0.074 \\
(0.092)\end{array}$ & & & & & & $\begin{array}{c}0.090 \\
(0.098)\end{array}$ & & & & \\
\hline Fewhhmembers_Group*Placebo_Tdummy & & $\begin{array}{c}0.026 \\
(0.084)\end{array}$ & & & & & & $\begin{array}{c}0.033 \\
(0.088)\end{array}$ & & & & \\
\hline Manyhhmembers_NOGroup*Placebo_Tdummy & & $\begin{array}{c}0.024 \\
(0.077)\end{array}$ & & & & & & $\begin{array}{c}0.033 \\
(0.084)\end{array}$ & & & & \\
\hline Manychild_Group*Tdummy (Aug 08) & & & $\begin{array}{c}-0.109 \\
(0.203)\end{array}$ & $\begin{array}{c}-0.082 \\
(0.204)\end{array}$ & & & & & $\begin{array}{c}-0.122 \\
(0.218)\end{array}$ & $\begin{array}{c}-0.093 \\
(0.218)\end{array}$ & & \\
\hline Fewchild_Group*Tdummy (Aug 08) & & & $\begin{array}{c}0.109 \\
(0.151)\end{array}$ & $\begin{array}{c}0.118 \\
(0.160)\end{array}$ & & & & & $\begin{array}{c}0.122 \\
(0.159)\end{array}$ & $\begin{array}{c}0.134 \\
(0.168)\end{array}$ & & \\
\hline Manychild_NOGroup*Tdummy (Aug 08) & & & $\begin{array}{c}-0.283^{* *} \\
(0.113)\end{array}$ & $\begin{array}{c}-0.293^{* *} \\
(0.121)\end{array}$ & & & & & $\begin{array}{c}-0.296 * * \\
(0.121)\end{array}$ & $\begin{array}{c}-0.305^{* *} \\
(0.130)\end{array}$ & & \\
\hline Manychild_Group & & & $\begin{array}{c}-0.656^{* * * *} \\
(0.220)\end{array}$ & $\begin{array}{c}-0.683^{* * * *} \\
(0.223)\end{array}$ & & & & & $\begin{array}{c}-0.706^{* * * *} \\
(0.224)\end{array}$ & $\begin{array}{c}-0.736^{* * * *} \\
(0.228)\end{array}$ & & \\
\hline Fewchild_Group & & & $\begin{array}{c}-0.204 \\
(0.166)\end{array}$ & $\begin{array}{c}-0.212 \\
(0.173)\end{array}$ & & & & & $\begin{array}{c}-0.147 \\
(0.177)\end{array}$ & $\begin{array}{c}-0.159 \\
(0.184)\end{array}$ & & \\
\hline Manychild_NOGroup & & & $\begin{array}{c}-0.404^{* * *} \\
(0.166)\end{array}$ & $\begin{array}{c}-0.395^{* *} \\
(0.170)\end{array}$ & & & & & $\begin{array}{c}-0.454^{* * * *} \\
(0.170)\end{array}$ & $\begin{array}{c}-0.445^{* * *} \\
(0.175)\end{array}$ & & \\
\hline Manychild_Group*Placebo_Tdummy & & & & $\begin{array}{c}0.053 \\
(0.078)\end{array}$ & & & & & & $\begin{array}{c}0.059 \\
(0.086)\end{array}$ & & \\
\hline Fewchild_Group*Placebo_Tdummy & & & & $\begin{array}{c}0.017 \\
(0.094)\end{array}$ & & & & & & $\begin{array}{c}0.025 \\
(0.099)\end{array}$ & & \\
\hline Manychild_NOGroup*Placebo_Tdummy & & & & $\begin{array}{c}-0.018 \\
(0.077)\end{array}$ & & & & & & $\begin{array}{c}-0.018 \\
(0.084)\end{array}$ & & \\
\hline Table_Contn. & & & & & & & & & & & & \\
\hline Manyfemale_Group*Tdummy (Aug 08) & & & & & $\begin{array}{c}-0.195 \\
(0.195)\end{array}$ & $\begin{array}{c}-0.151 \\
(0.195)\end{array}$ & & & & & $\begin{array}{c}-0.212 \\
(0.211)\end{array}$ & $\begin{array}{c}-0.162 \\
(0.211)\end{array}$ \\
\hline Fewfemale_Group*Tdummy (Aug 08) & & & & & $\begin{array}{c}0.154 \\
(0.148)\end{array}$ & $\begin{array}{c}0.173 \\
(0.155)\end{array}$ & & & & & $\begin{array}{c}0.163 \\
(0.156)\end{array}$ & $\begin{array}{c}0.187 \\
(0.163)\end{array}$ \\
\hline Manyfemale_NOGroup*Tdummy (Aug 08) & & & & & $\begin{array}{c}-0.291 * * \\
(0.119)\end{array}$ & $\begin{array}{c}-0.266^{* *} \\
(0.126)\end{array}$ & & & & & $\begin{array}{c}-0.305^{* *} \\
(0.126)\end{array}$ & $\begin{array}{c}-0.277^{* *} \\
(0.134)\end{array}$ \\
\hline Manyfemale_Group & & & & & $\begin{array}{l}-0.355 \\
(0.242)\end{array}$ & $\begin{array}{l}-0.399 \\
(0.244)\end{array}$ & & & & & $\begin{array}{c}-0.321 \\
(0.252)\end{array}$ & $\begin{array}{c}-0.370 \\
(0.254)\end{array}$ \\
\hline Fewfemale_Group & & & & & $\begin{array}{c}-0.169 \\
(0.153)\end{array}$ & $\begin{array}{c}-0.188 \\
(0.159)\end{array}$ & & & & & $\begin{array}{c}-0.136 \\
(0.163)\end{array}$ & $\begin{array}{c}-0.160 \\
(0.169)\end{array}$ \\
\hline Manyfemale_NOGroup & & & & & $\begin{array}{c}-0.083 \\
(0.194)\end{array}$ & $\begin{array}{c}-0.109 \\
(0.196)\end{array}$ & & & & & $\begin{array}{c}-0.098 \\
(0.205)\end{array}$ & $\begin{array}{c}-0.126 \\
(0.207)\end{array}$ \\
\hline Manyfemale_Group*Placebo_Tdummy & & & & & & $\begin{array}{c}0.088 \\
(0.084)\end{array}$ & & & & & & $\begin{array}{c}0.099 \\
(0.093)\end{array}$ \\
\hline Fewfemale_Group*Placebo_Tdummy & & & & & & $\begin{array}{c}0.039 \\
(0.085)\end{array}$ & & & & & & $\begin{array}{c}0.047 \\
(0.090)\end{array}$ \\
\hline Manyfemale_NOGroup*Placebo_Tdummy & & & & & & $\begin{array}{c}0.051 \\
(0.079)\end{array}$ & & & & & & $\begin{array}{c}0.056 \\
(0.085)\end{array}$ \\
\hline HH migration experience (current) & $\begin{array}{c}0.599 * * * \\
(0.110)\end{array}$ & $\begin{array}{c}0.599^{* * *} * \\
(0.110)\end{array}$ & $\begin{array}{c}0.618^{* * *} \\
(0.107)\end{array}$ & $\begin{array}{c}0.618^{* * *} \\
(0.107)\end{array}$ & $\begin{array}{c}0.652^{* * *} \\
(0.107)\end{array}$ & $\begin{array}{c}0.652 * * * \\
(0.107)\end{array}$ & $\begin{array}{c}0.673^{* * * *} \\
(0.114)\end{array}$ & $\begin{array}{c}0.673 * * * \\
(0.114)\end{array}$ & $\begin{array}{c}0.703^{* * * *} \\
(0.112)\end{array}$ & $\begin{array}{c}0.703 * * * \\
(0.112)\end{array}$ & $\begin{array}{c}0.723^{* * *} * \\
(0.112)\end{array}$ & $\begin{array}{c}0.724^{* * *} * \\
(0.112)\end{array}$ \\
\hline HH migration experience (past) & $\begin{array}{c}0.455 * * * \\
(0.123)\end{array}$ & $\begin{array}{c}0.455^{* * * *} \\
(0.123)\end{array}$ & $\begin{array}{c}0.456^{* * * *} \\
(0.125)\end{array}$ & $\begin{array}{c}0.456^{* * * *} \\
(0.125)\end{array}$ & $\begin{array}{c}0.469^{* * * *} \\
(0.123)\end{array}$ & $\begin{array}{c}0.469 * * * \\
(0.123)\end{array}$ & $\begin{array}{c}0.524^{* * * *} \\
(0.129)\end{array}$ & $\begin{array}{c}0.524^{* * *} \\
(0.129)\end{array}$ & $\begin{array}{c}0.529 * * * * \\
(0.129)\end{array}$ & $\begin{array}{c}0.529 * * * \\
(0.129)\end{array}$ & $\begin{array}{c}0.540^{* * * *} \\
(0.128)\end{array}$ & $\begin{array}{c}0.540^{* * *} \\
(0.128)\end{array}$ \\
\hline $\mathrm{HH}$ and community controls & yes & yes & yes & yes & yes & yes & yes & yes & yes & yes & yes & yes \\
\hline Community fe & no & no & no & no & no & no & yes & yes & yes & yes & yes & yes \\
\hline Observations & 2,701 & 2,701 & 2,701 & 2,701 & 2,701 & 2,701 & 2,701 & 2,701 & 2,701 & 2,701 & 2,701 & 2,701 \\
\hline
\end{tabular}

